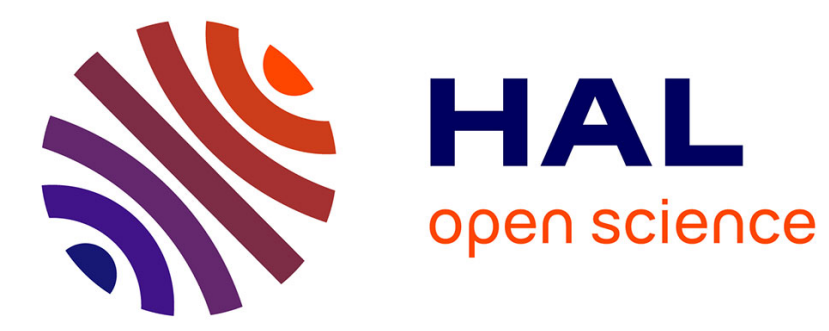

\title{
Neogene strike-slip faulting in Sakhalin and the Japan Sea opening
}

Marc Fournier, Laurent Jolivet, Philippe Huchon, Konstantin F. Sergeyev, Leonid Oscorbin

\section{- To cite this version:}

Marc Fournier, Laurent Jolivet, Philippe Huchon, Konstantin F. Sergeyev, Leonid Oscorbin. Neogene strike-slip faulting in Sakhalin and the Japan Sea opening. Journal of Geophysical Research : Solid Earth, 1994, 99 (B2), pp.2701-2725. 10.1029/93JB02026 . insu-00726734

\section{HAL Id: insu-00726734 https://hal-insu.archives-ouvertes.fr/insu-00726734}

Submitted on 31 Aug 2012

HAL is a multi-disciplinary open access archive for the deposit and dissemination of scientific research documents, whether they are published or not. The documents may come from teaching and research institutions in France or abroad, or from public or private research centers.
L'archive ouverte pluridisciplinaire HAL, est destinée au dépôt et à la diffusion de documents scientifiques de niveau recherche, publiés ou non, émanant des établissements d'enseignement et de recherche français ou étrangers, des laboratoires publics ou privés. 


\title{
Neogene strike-slip faulting in Sakhalin and the Japan Sea opening
}

\author{
Marc Fournier, Laurent Jolivet, and Philippe Huchon \\ Laboratoire de Géologie, Département Terre Atmosphère Ocean, Ecole Normale Supérieure, Paris \\ Konstantin F. Sergeyev and Leonid S. Oscorbin \\ Institute of Marine Geology and Geophysics, Far East Science Center, Yuzhno-Sakhalinsk, Russia
}

We describe structural data from a $2000 \mathrm{~km} \mathrm{~N}-\mathrm{S}$ dextral strike-slip zone extending from northem Sakhalin to the southeast comer of the Japan Sea. Satellite images, field data, and focal mechanisms of earthquakes in Sakhalin are included in the interpretation. Since Miocene time the deformation in Sakhalin has been taken up by N-S dextral strike-slip faults with a reverse component and associated en échelon folds. Narrow en échelon Neogene basins were formed along strike-slip faults and were later folded in a second stage of deformation. We propose a model of basin formation along extensional faults delimitating dominos between two major strike-slip faults, and subsequent counterclockwise rotation of the dominos in a dextral transpressional regime, basins becoming progressively oblique to the direction of maximum horizontal compression and undergoing shortening. The association of both dextral and compressional focal mechanisms of earthquakes indicates that the same transpressional regime still prevails today in Sakhalin. We present fault set measurements undertaken in Noto Peninsula and Yatsuo Basin at the southem end of the Sakhalin-East Japan Sea strike-slip zone. Early and middle Miocene formations recorded the same transtensional regime as observed along the west coast of NE Honshu. During the early and middle Miocene the strike-slip regime was transpressional to the north in Sakhalin and Hokkaido, and transtensional to the south along the west coast of NE Honshu as far as Noto Peninsula and Yatsuo basin. Dextral motion accommodated the opening of the Japan Sea as a pull-apart basin, with the Tsushima fault to the west. The opening of the Japan Sea ceased at the end of the middle Miocene when transtension started to change to E-W compression in the Japan arc. Subduction of the Japan Sea lithosphere under the Japan arc started 1.8 Ma ago. The evolution of the stress regime from transtensional to compressional in the southem part of the strike-slip zone is related to the inception of the subduction of the young Philippine Sea Plate lithosphere under the Japan arc during the late Miocene. Subduction related extension is a necessary condition for the opening of the Japan Sea. Two possible mechanisms can account for dextral shear in this area: (1) counterclockwise rotation of crustal blocks due to the collision of India with Asia, (2) extrusion of the Okhotsk Sea block squeezed between the Norh America and Eurasia plates.

\section{INTRODUCTION}

Deformation resulting from the India-Asia collision is taken up by crustal thickening in the Himalaya-Tibet collision zone and by geometric reorganization of continental blocks accommodated by strike-slip motion along major faults [Molnar and Tapponnier, 1975; Tapponnier and Molnar, 1976; Zonenshain and Savostin, 1981; Cobbold and Davy, 1988; England and Molnar, 1990; Holt et al., 19911. Along the southeastem limit of Asia, strike-slip faults accommodated the opening of two marginal basins: the Andaman Sea in the prolongation of the Sagaing fault and Shan scarp system [Curray et al., 1979; Tapponnier et al., 1986], and possibly the South China Sea along the extension of the Red River fault [Tapponnier et al., 1982, 1986; Briais et al., 1993].

In northeast Asia, at the end of the Tien Shan-BaikalStanovoy deformation zone, the Japan and Okhotsk Seas (Figure 1) opened in the Early and Middle Miocene. The oldest oceanic basalts drilled on the eastern margin of the Japan Sea during Ocean Drilling Program leg 127 have a radiometric ${ }^{40} \mathrm{Ar}-{ }^{39} \mathrm{Ar}$ age of $24 \mathrm{Ma}$ [Tamaki et al., 1992] and the

Copyright 1994 by the American Geophysical Union.

Paper number 93JB02026.

0148-0227/94/93JB-02026\$05.00 youngest dredged basaltic volcanics were dated $11 \mathrm{Ma}$ [Kaneoka et al., 1990]. These ages are in good agreement with an earlier determination of the age of Japan Sea basement based on geophysical data between 30 and $10 \mathrm{Ma}$ [Tamaki, 1986, 1988]. Similar average heat flow value and basement depth in both Japan and Kuril Basins led Tamaki [1988] to conclude to a simultaneous opening of the two basins in the late Oligocene to middle Miocene. Otsuki and Ehiro [1978] first outlined the role of strike-slip faults in the opening of the Japan Sea and proposed a drawerlike model of opening between the left-lateral Tanakura tectonic line (TTL) to the east and the right-lateral Tsushima fault (TF) to the west. Kimura et al. [1983] and Jolivet and Miyashita [1985] described onland transpressional deformation associated with N-S dextral strike-slip motion in Sakhalin and Hokkaido during the Oligocene and Miocene. Lallemant and Jolivet [1985] proposed a model of opening of the Japan Sea as a simple dextral pull-apart basin between this strike-slip zone to the east, and the Tsushima fault to the west. Jolivet et al. [1991], using analogue laboratory modelling, refined the pull-apart model by introducing blocks rotations in the dextral shear zone, that only partly fit the paleomagnetic data. Jolivet [1986] associated the dextral motion to southward extrusion of the Okhotsk Sea block squeezed between the North America and the Eurasia plates. Kimura and Tamaki [1986] and Jolivet et al. [1990] finally related the opening of the Japan and Okhotsk Seas to the motions of Asian microplates as a consequence of the India-Asia collision. 


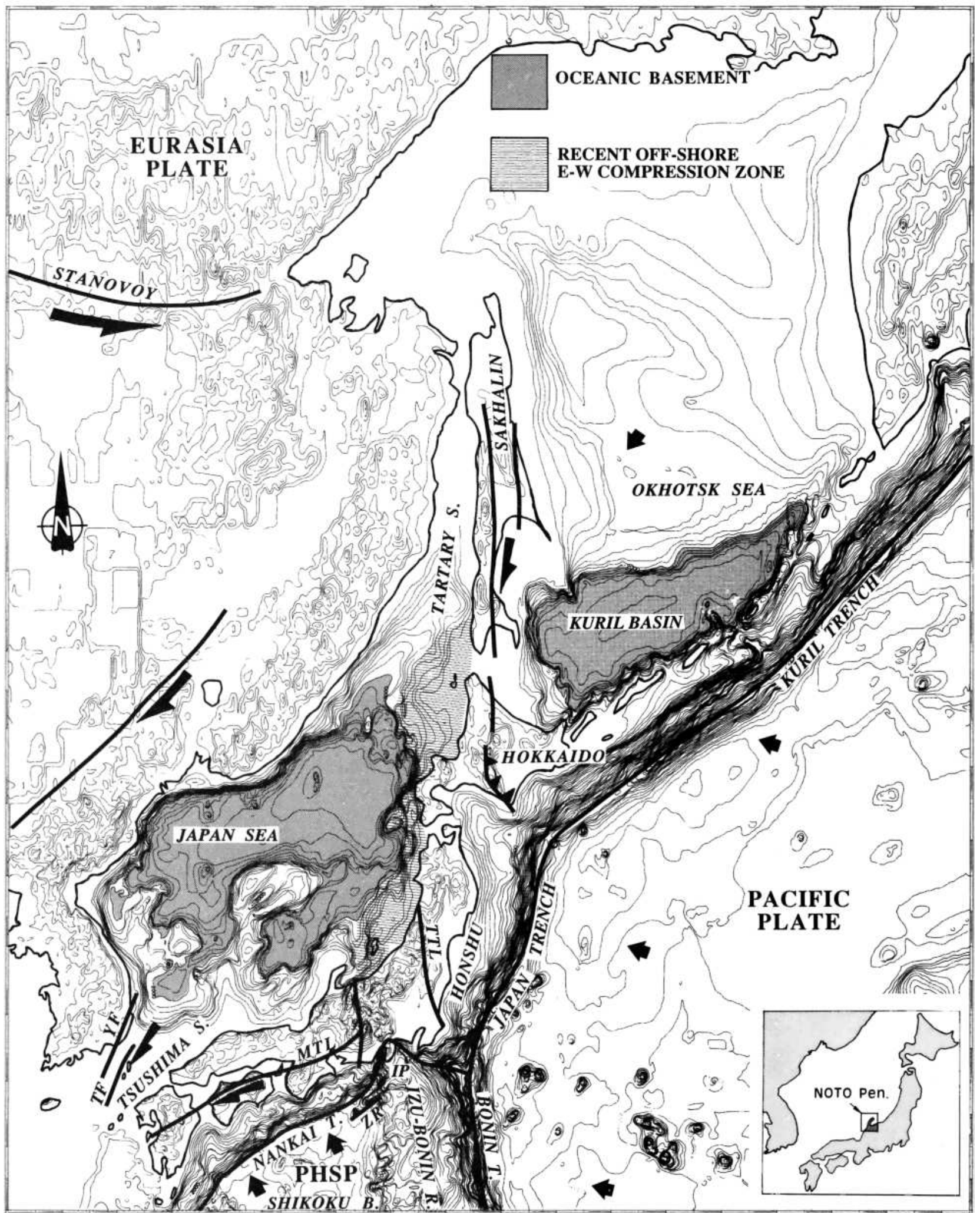

Fig. 1. Simplified structural map of far east Asia with topography and bathymetry. Solid arrows give directions of motions of Pacific and Okhotsk plates relative to Asia. B is basin, IP is lzu Peninsula, MTL is median tectonic line, $R$ is ridge, $S$ is strait, T is trench, TF is Tsushima fault, TTL is Tanakura tectonic line, YF is Yangsan fault, and ZR is Zenisu ridge.

The eastern guide of the Japan Sea dextral pull-apart is a 2000-km-long strike-slip zone extending from the northem end of Sakhalin island to the north, to the southeast corner of the Japan Sea to the south (Figure 2)[Kimura et al., 1983; Lallemant and Jolivet, 1985]. The central part of the strikeslip zone from Hokkaido to the west coast of NE Honshu is described by Lallemant and Jolivet [1985], Jolivet and Huchon [1989] and Jolivet et al. [1991]. In Sakhalin, field studies showed that the island is cut by a N-S trending faults system [Zanyukov, 1971; Rozhdestvensky, 1982] which is responsible for the intense shallow seismicity of the island [e.g., Oskorbin, 1977; Savostin et al., 1983; Tarakamov and 


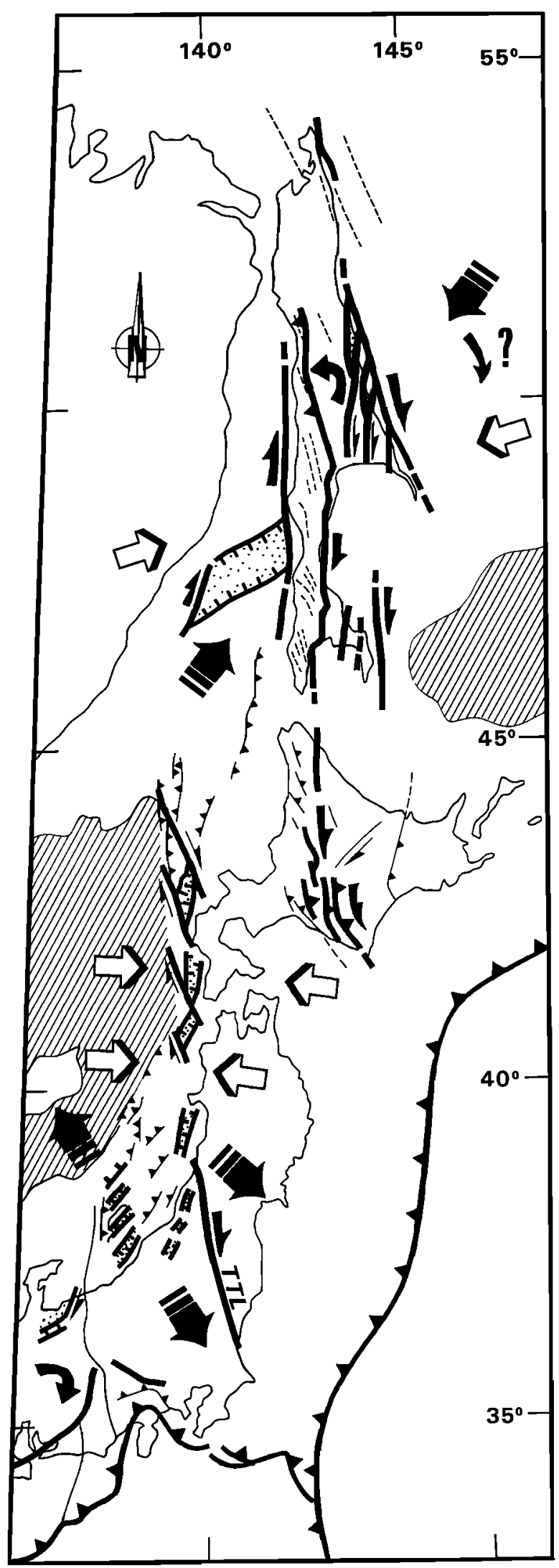

Fig. 2. Tectonic map of the Sakhalin-East Japan Sea strike-slip zone. Solid arrows represent early and middle Miocene main stress field directions, transpressional to the north in Sakhalin and Hokkaido, and transtensional the south along the eastem margin of the Japan Sea (with dextral en échelon basins). Open arrows represent upper Miocene and Pliocene main stress field directions, still transpressional in Sakhalin and purely compressional in the Japan arc. Changes of stress field directions in the south of the strike-slip zone correspond to change of subduction
Kim, 1983]. Field observations by Rozhdestvensky [1982] described dextral Miocene strike-slip motion along the faults. In this paper we describe both the north and the south ends of the strike-slip zone, respectively, in Sakhalin and Central Japan.

We first present a study of the strike-slip zone in Sakhalin based on the structural interpretation of Landsat images, results of field work in 1989 and 1990 along the TymPoronaysk fault and in the East Sakhalin Mountains, and fault plane solutions for major earthquakes since 1960 [this study; Fukao and Furumoto, 1975; Dziewonski et al., 1985; 1987]. We confirm the conclusions of Rozhdestvensky [1982]: the island is a right-lateral strike-slip zone of Neogene age. Dextral motion is inferred from large-scale geological structures observed on the satellite images. Small-scale fault measurements in Neogene deposits provide maximal horizontal stress directions compatible with the dextral motion along the N-S faults. Seismological data show that the dextral motion is still active today. We propose a model of progressive strike-slip deformation with block rotations about vertical axes to explain the later shortening of the Neogene dextral en échelon basins. In a second part we infer the Miocene paleostress field from fault measurements undertaken in Noto peninsula and Yatsuo basin (central Japan, Figure 1) at the southern extremity of the Sakhalin-East Japan Sea strike-slip zone. Miocene formations recorded there the same transtensional deformation as observed along the west coast of NE Honshu [Jolivet et al., 1991]. We conclude by discussing the evolution of the strike-slip zone from the Miocene to the present, e.g., from the pull-apart opening of the Japan Sea to its present-day incipient closure.

\section{PRESENT-Day Geodynamic SETTTNG}

The Japan island arc lies above the old Pacific slab to the east which is subducted westward at a high rate of $10 \mathrm{~cm} / \mathrm{yr}$, and above the younger slab of the Philippine Sea Plate to the south which underthrusts Japan at a slower rate of a few centimeters per year (Figure 1) [Matsukata et al., 1991]. The Philippine sea plate (PHSP)/Eurasia (EUR) rotation pole is located immediately north of the PHSP/EUR/Pacific (PAC) triple junction [Seno, 1977; Ranken et al., 1984; Huchon, 1985]. The slightly oblique subduction of the PHSP in the Nankai trench is partitioned between compressional deformation in the trench and slow dextral motion along the median tectonic line (MTL) in southwest Japan. A large accretionary prism is progressively built up in the Nankai trench at the expense of trench turbidites [Le Pichon et al., 1987; Le Pichon, Kobayashi et al., 1992]. Close to the triple junction the Bonin arc collides with Central Japan giving rise to active thrusting north of the Izu Peninsula with a fan-shaped stress pattern [Huchon, 1985]. Active compression propagates southward inside the Bonin arc and Shikoku Basin with the formation of crustal scale shortening thrust (Zenisu ridge) [Lallemant et al., 1989; Chamot-Rooke and Le Pichon, 1989].

The Pacific plate is consumed in the Bonin, Japan and Kuril trenches which are almost devoid of turbidites infill, and where fast erosion of the inner wall and tectonic erosion are the major phenomena [Cadet et al., 1987a, 1987b; Von Huene and Lallemand, 1990]. A compressional stress field dominates in northeast Japan with an E-W direction of compression almost parallel to the PAC/EUR motion vector. Active shortening is observed along the eastem margin of the Japan Sea as a zone of shallow seismicity (Figure 1) with large

regime from stress-free to compressional during late Miocene. The possible clockwise rotation of the stess field in Sakhalin is discussed in the texL. TTL is Tanakura tectonic line. 
earthquakes $(M>7.5)$ evidencing E-W compression [Fukao and Furumoto, 1975] taken up by thrust faults [Tamaki and Honza, 1984; Lallemand and Jolivet, 1985]. This active deformation has been interpreted as the incipient subduction of the young Japan Sea lithosphere under northeast Japan [Nakamura,

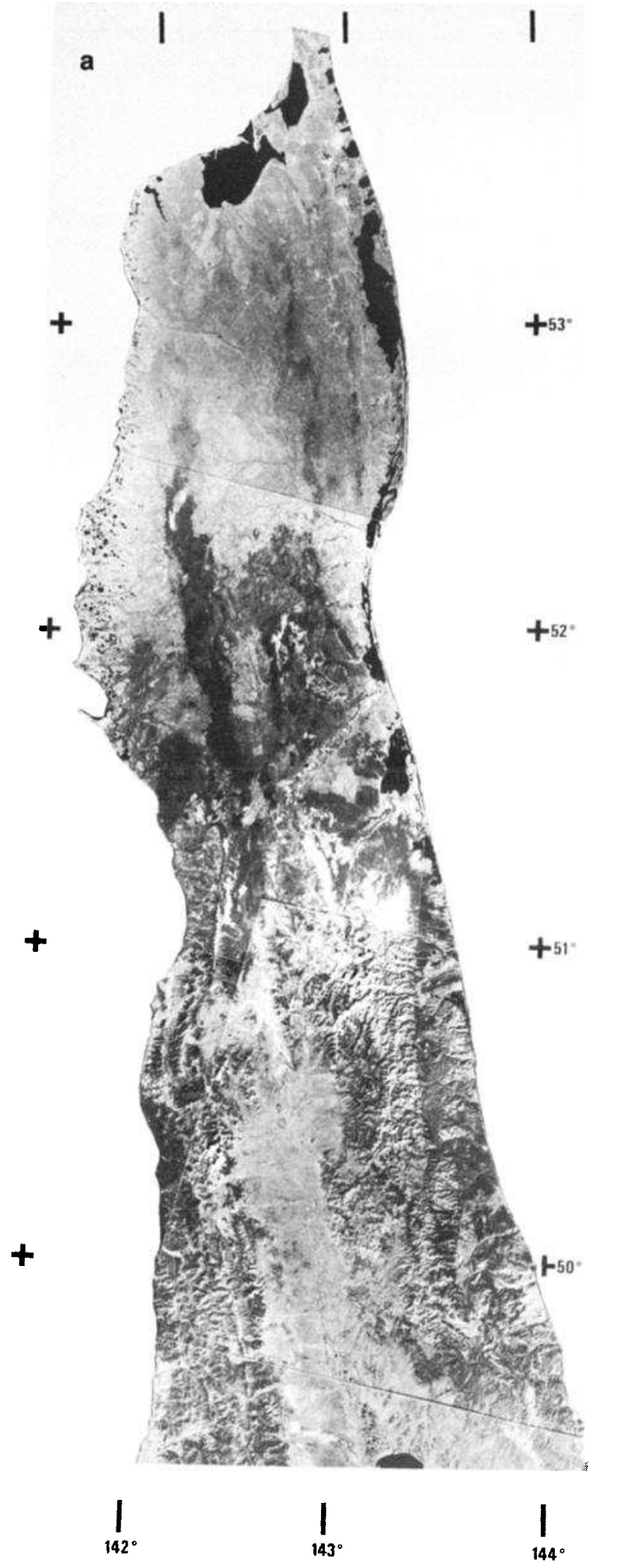

1983]. The seismogenic zone extends northward in Sakhalin where both pure compressional and pure strike-slip events are recorded [Chapman and Solomon, 1976; Savostin et al., 1983; this study]. Seismicity activity also occurs in the western part of the Japan Sea displaying dextral strike-slip events along NE trending faults in the Tsushima strait [Jun, 1990]. Within the Asian continent dextral motions along NE trending faults control the formation of pull-apart basins in the Bohai Gulf region [Chen and Nabelek, 1988].

\section{Transpressional. Deformation In SAKhalin}

In order to get information at the scale of the entire shear zone located east of the Japan Sea, the precise geometry of the whole strike-slip system in Sakhalin has to be known. For
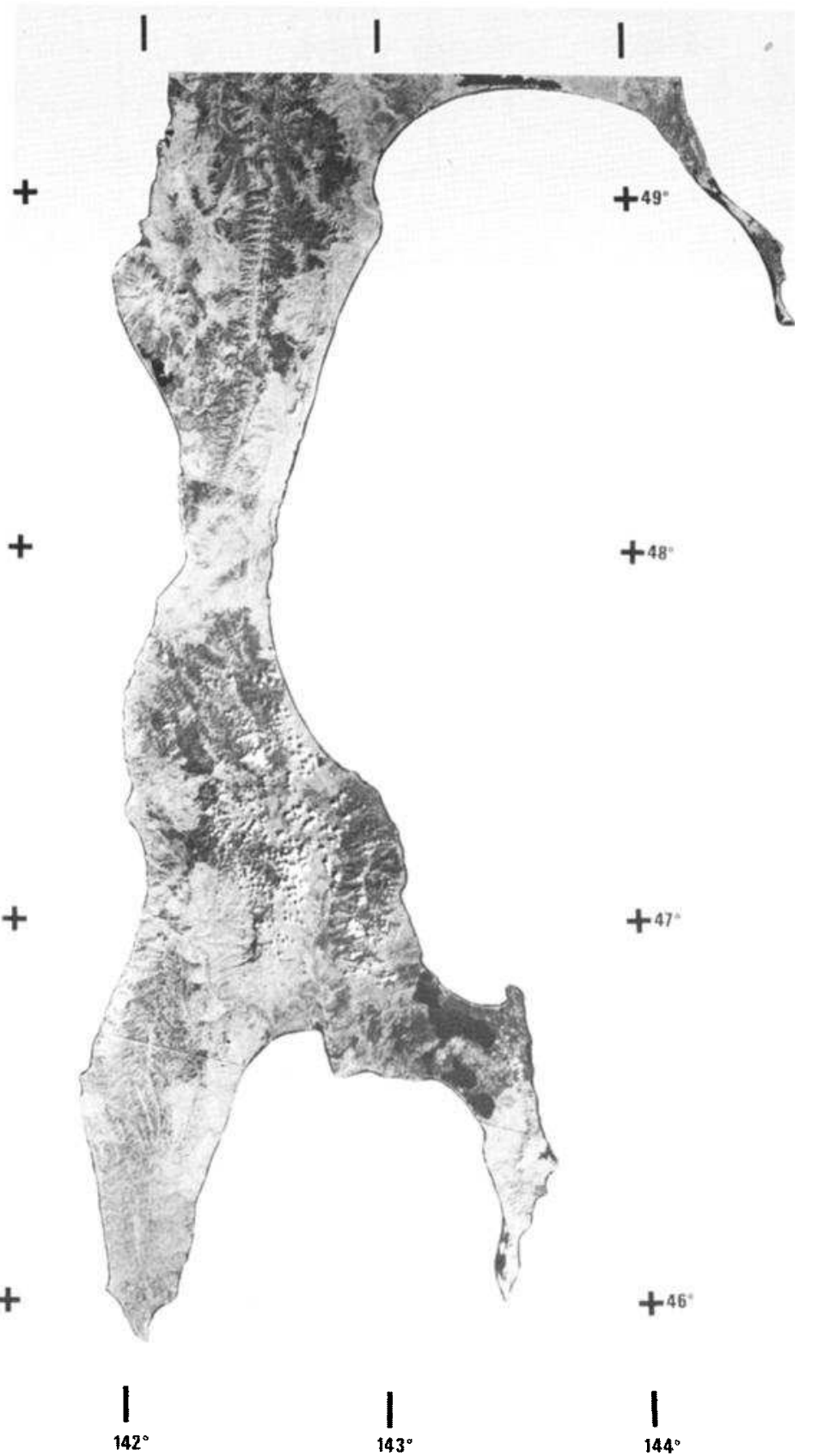

Fig. 3. (a) Sketch of Landsat images of Sakhalin. (b) Seismotectonic map of Sakhalin. For fault plane solution (lower hemisphere), $T$ quadrants (compressional quadrants) are shown in shaded areas and $P$ quadrants (dilatational quadrants) are open areas. Solid $T$ quadrants correspond to fault plane solutions determined by Oscorbin, vertically ruled $T$ quadrants correspond to fault plane solutions determined by $F$ ukao and Furumoto [1975], and horizontally ruled $T$ quadrants correspond to centroid moment tensor determined by Dziewonski $e t$ al. [1985, 1987]. Paleo-stress field horizontal directions deduced from (c) Geological map. 

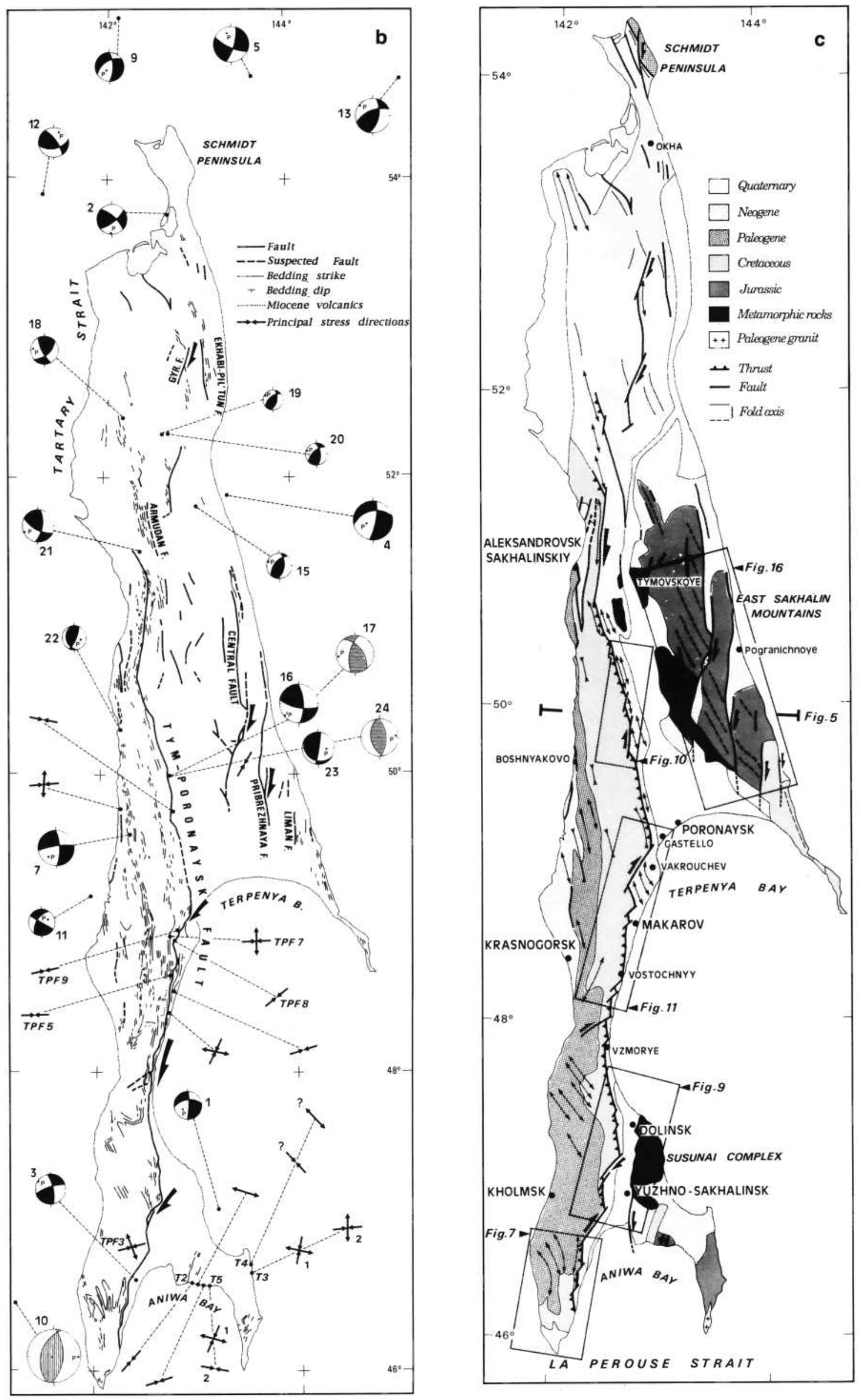

Fig. 3. (continued) 
this purpose we studied Landsat Thematic Mapper images with natural color on $240-\mathrm{mm}$ paper at the scale of $1 / 1000000$. The mosaic covers the entire island except the northern Schmidt peninsula (Figure 3c). Our map shows geological objects such as sedimentary layers with indication of dips, folds, faults, major volcanic intrusions and sedimentary basins. Despite a dense vegetation cover, the morphological signature of the geological formations allowed simple large-scale mapping. Working with the $1 / 1000000$ geological map of Sakhalin [Geology of the USSR, 1970], it was possible to draw a largescale geologic map consistent with our observations. The results are presented in Figure $3 a$, the Landsat image mosaic, Figure $3 b$, a data map showing the structures observed on the images, the paleo-stress field directions measured on the field and the focal mechanisms of earthquakes, and Figure $3 c$, an interpretative geological map. The geometry of the major dislocation, the Tym-Poronaysk fault, is detailed. Using six SPOT images we studied at a smaller scale three regions located along the Tym-Poronaysk fault (see location in Figure $3 c$ ). For each region we present a sketch of two SPOT images with its structural interpretation. In the central region, the geologic map is compiled from $K$. $F$. Sergeyev (unpublished data, 1980), the geologic map of Sakhalin, and our new observations.

\section{Geological Setting}

Sakhalin island is $1000 \mathrm{~km}$ long and 30 to $180 \mathrm{~km}$ wide. It is structuraly divided in two parts by the Tym-Poronaysk fault that bounds to the west a central depression filled with quaternary deposits (see geological map Figure $3 c$ ). To the east of the depression, the East Sakhalin Mountains (in the north) and the Susunai metamorphic complex (in the south) display a Paleozoic basement metamorphosed during Mesozoic time, with eclogitic and high-pressure/low-temperature parageneses. The basement is overlain by a pile of Mesozoic (JurassicCretaceous) deep sea sediments consisting of a folded and schistosed tectonic alternation of cherts, blackshales and basalts, described as an ancient accretionary complex [Zonenshain et al., 1990; Kimura et al., 1992]. These formations are cut by N-S trending faults bounding narrow basins in which Neogene sediments were unconformably deposited and later folded. To the west, the Tym-Poronaysk fault bounds the West Sakhalin Mountains, folded strata of Upper Cretaceous to Quaternary age. The thick Upper Cretaceous (Cenomanian to Danian) sequence lays unconformably over a Paleozoic and Mesozoic basement similar to that of the East Sakhalin mountains [Melnikov, 1987; Melnikov and Rozhdestvensky, 1989]. Three transgressive cycles are recognized during the Late Cretaceous in the northern part of the west Sakhalin basin (Figure 4), with deepening sequences of terrigeneous deposits showing successively coal-bearing continental deposits, sandstones and claystones. The base of the Paleogene is marked by a conglomerate of variable thickness (up to $600 \mathrm{~m}$ ), overlain by two transgressive sequences of terrigeneous deposits, with a thick volcanogenic layer at the top (Takaradaï and Maruyama formations). To the east of the Tym-Poronaysk fault (Figure 4)

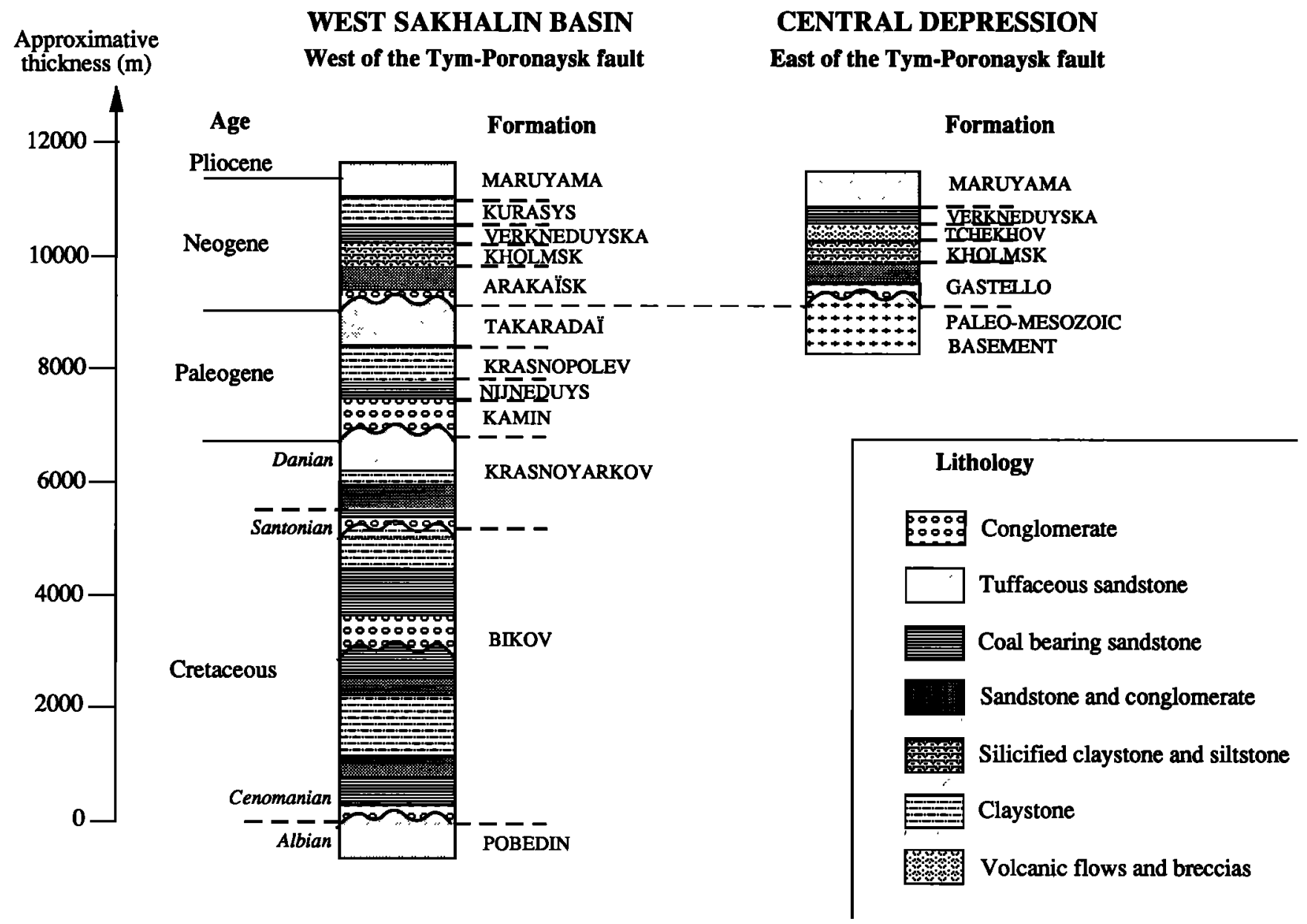

Fig. 4. Detailed stratigraphic and lithological section of the west Sakhalin Mountains and the Central Depression at Vakrouchev latitude. 
the Neogene deposits lay directly on the Palezoic-Mesozoic basement as shown by drilling in the central NeogeneQuaternary depression [Rozhdestvensky, 1982]. The Cretaceous sequence to the west and Neogene formations to the east are in contact across the fault. Basic sills and dykes of Neogene age are emplaced in the vicinity of the fault.

An E-W synthetic cross section of Sakhalin island is presented in Figure 5 after Rozhdestvensky [1982], Pushcharovskiy et al. [1983], and our field observations (see location of the cross section in Figure $3 c$ ). The TymPoronaysk fault is localized along the boundary between a Mesozoic accretionary complex to the east and a sedimentary basin of Upper Cretaceous age to the west. The sedimentary Upper Cretaceous and Cenozoic sequence in this basin is about $10 \mathrm{~km}$ thick. The Tym-Poronaysk fault might have reworked an inherited Cretaceous structure as a strike-slip reverse fault.

Seismic data show that the off shore structure in the vicinity of the island is similar to the onland structure. Along the east coast of Sakhalin Gnibidenko and Svarichevsky [1984] and Gnibidenko [1985] described N-S trending faults parallel to the Tym-Poronaysk fault. The northeast coast of Sakhalin is limited by off shore faults several hundred kilometers long, bounding narrow basins filled with Cenozoic sediments more than $5000 \mathrm{~m}$ thick. The southwest coast is bordered by the West Sakhalin fault parallel to the TymPoronaysk fault, and which is observed onland in Boshnyakovo region (Figures 2 and $3 c$ ). Along this coast Antipov et al. [1979] described en échelon narrow basins with a north-northeast trend filled with 2000-m-thick middle Miocene and younger sediments. Such basins similar to these described by Lallemand and Jolive [1985] along the northwest coast of Honshu may be interpreted as dextral en échelon structures associated with the West Sakhalin fault.

\section{Active Strike-Slip Motion Along the Tym-Poronaysk Fault}

The Tym-Poronaysk fault is seismically active and has caused most of the onland main earthquakes of Sakhalin [Oscorbin, 1977; see Chapman and Solomon, 1976; Savostin et al., 1983]. In contrast, the faults cutting through the East Sakhalin Mountains are seismically inactive. Fault plane solutions (Table 1) of shallow earthquakes (depth less than 30 km) determined in this study (by $L . S$. Oscorbin), Fukao and Furumoto [1975], and centroid moment tensors determined by Dziewonski et al. $[1985,1987]$ are plotted in Figure $3 b$. The focal mechanisms were determined by utilizing $P$ wave first motions detected by a Soviet regional seismological network. The radius of the focal mechanisms is a function of the magnitude (surface waves) of the earthquakes except for those taken from Dziewonski et al. [1985, 1987] which are kept constant in size. When two focal mechanisms were determined for an earthquake and its aftershock, we only plotted the focal mechanism corresponding to the main event. The two centroid moment tensors determined by Dziewonski et al. [1985, 1987] correspond to two earthquakes whose fault plane solutions have independently been determined in this study (for simplicity we only indicate our epicenter locations). The $P$ axes are almost similar in both cases, and the $T$ axes of the Dziewonski et al. $[1985,1987]$ focal mechanisms are steeper so that they indicate compressional motion when ours indicate strike-slip motion.

Most of the mechanisms determined along the TymPoronaysk fault evidences dextral strike-slip motion on the fault. The same observation applies to the West Sakhalin fault which parallels the Tym-Poronaysk fault along the westem coast. Focal mechanisms of the northern offshore earthquakes are not consistent with onshore focal mechanisms; they are not even internally consistent and are not clearly related to surface structures. Savostin et al. [1983] saw evidence of dextral motion along NNW trending faults in this region. At island scales, two categories of focal mechanisms are represented: strike-slip ones essentially located in the vicinity of the Tym-Poronaysk fault and consistent with dextral motion along it, and compressional ones evidencing E-W shortening taken up along N-S trending faults. We therefore conclude that Miocene transpressional dextral strikeslip motion continues at present in Sakhalin.

Assuming that the regional stress field is simple and does not show major local variations of the directions of the principal stress axes, $P$ and $T$ axes plotted on a stereographic projection may be used to infer a regional stress tensor (Figure 6). Hereafter, $\sigma_{1}, \sigma_{2}$, and $\sigma_{3}$ will refer to the principal axes of the stress tensor, with $\sigma_{1}>\sigma_{2}>\sigma_{3}$. The best $P$ and $T$ axes directions determined with the right dihedra method |Angelier and Mechler, 1977) are assumed to be $\sigma_{1}$ and $\sigma_{3}$, respectively. The result show $\sigma_{l}$ almost horizontal and trending ENE-WSW. Directions and dips of $\sigma_{2}$ and $\sigma_{3}$ are poorly constrained as both compressional and strike-slip focal mechanisms coexist. Though it is questionable in general that a small number of focal mechanisms can be used to compute a mean regional stress tensor, the result we obtain is very similar to the results of fault sets analysis undertaken in Sakhalin and described later, with roughly the same trend of $\sigma_{l}$ though sometimes more northerly. This suggests that both Miocene and presentday seismic deformation patterns were governed by a similar overall stress field. However, there is a possibility that $\sigma_{1}$ rotated slightly clockwise toward a more latitudinal orientation, as we will discuss later.
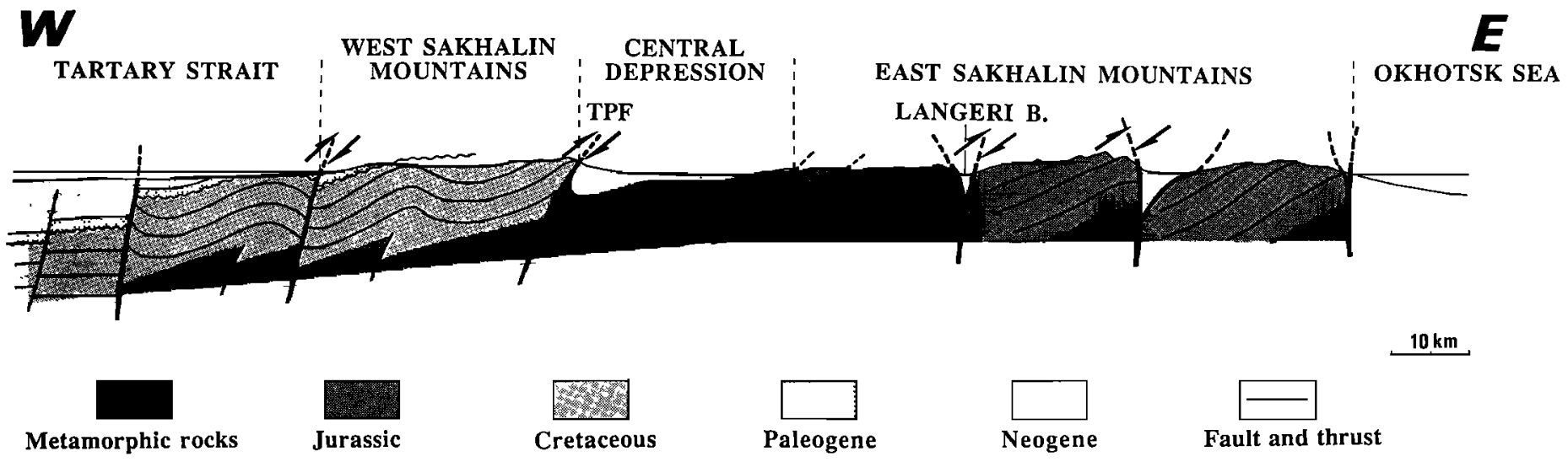

Fig. 5. East-west cross section of Sakhalin, localized in Figure 3c. B is basin, TPF is Tym-Poronaysk fault. 
TABLE 1. List of Source Parameter Results for 24 Earthquakes Ploted in Figure $3 b$.

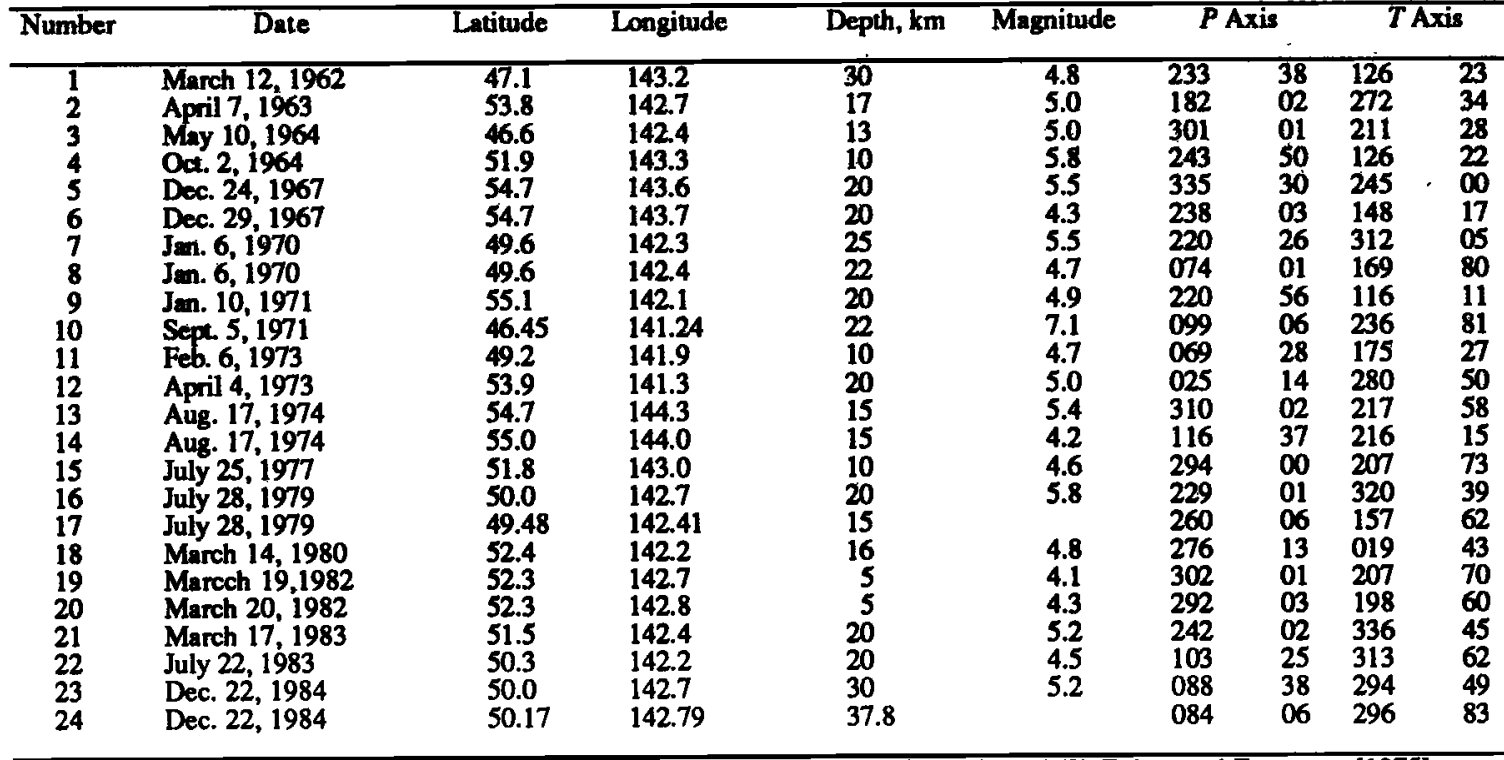

Neogene Strike-Slip Deformation Along the Tym-Poronaysk Fault

The Tym-Poronaysk fault is the major geological feature of Sakhalin. It is $600 \mathrm{~km}$ long and disappears to the north under Quaternary deposits and to the south in the La Pérouse Strait between Sakhalin and Hokkaido. It extends in Hokkaido as the Horonoba fault and the Hidaka mountains [Kimura et al., 1983; Jolivet and Miyashita, 1985]. In Sakhalin, the fault trends roughly N-S, bracketed between $142^{\circ} \mathrm{E}$ and $143^{\circ} \mathrm{E}$. The fault trace consists of a succession of nearly linear segments, the longer ones trending $\mathrm{N} 160^{\circ} \mathrm{E}$ to $\mathrm{N} 180^{\circ} \mathrm{E}$ are shifted dextrally by shorter ones trending $\mathrm{N} 010^{\circ} \mathrm{E}$ to $\mathrm{N} 045^{\circ} \mathrm{E}$ (Figures $3 b$ and $3 c$ ). The ratio of long and short segments determines the mean trend of the fault: N-NW from north of the island to Poronaysk city in the central part with only three short $\mathrm{N} 010^{\circ} \mathrm{E}$ to $\mathrm{N} 045^{\circ} \mathrm{E}$ trending segments (Figure $3 \mathrm{c}$ ), and N-NE to the south with many dextrally shifting short segments. Bedding traces are parallel to the long segments and are strained by dextral shear along the short ones. This is observed in the YuzhnoSakhalinsk region to the south, and in the Poronaysk region in the central part of the island (Figures $3 b$ and $3 c$ ). The same geometry is observed with the axes of en échelon folds affecting the whole sedimentary section (upper Cretaceous to upper Miocene) on each side of the fault. The fold axes trend $\mathrm{N} 140^{\circ} \mathrm{E}$ to $\mathrm{N} 180^{\circ} \mathrm{E}$, roughly parallel to the long segments of the fault, and are strained by dextral shear along the short segments. There is a single exception in the Vostochnyy region where a fold trends northwesterly. This fold could be older than the others as it affects only Cretaceous and Paleogene formations. Figure 7 shows a detail of the Landsat image of the southwestern peninsula of the island. Four dextral en échelon folds in Miocene formations are strained by dextral shear along the Tym-Poronaysk fault. Neogene deposits of
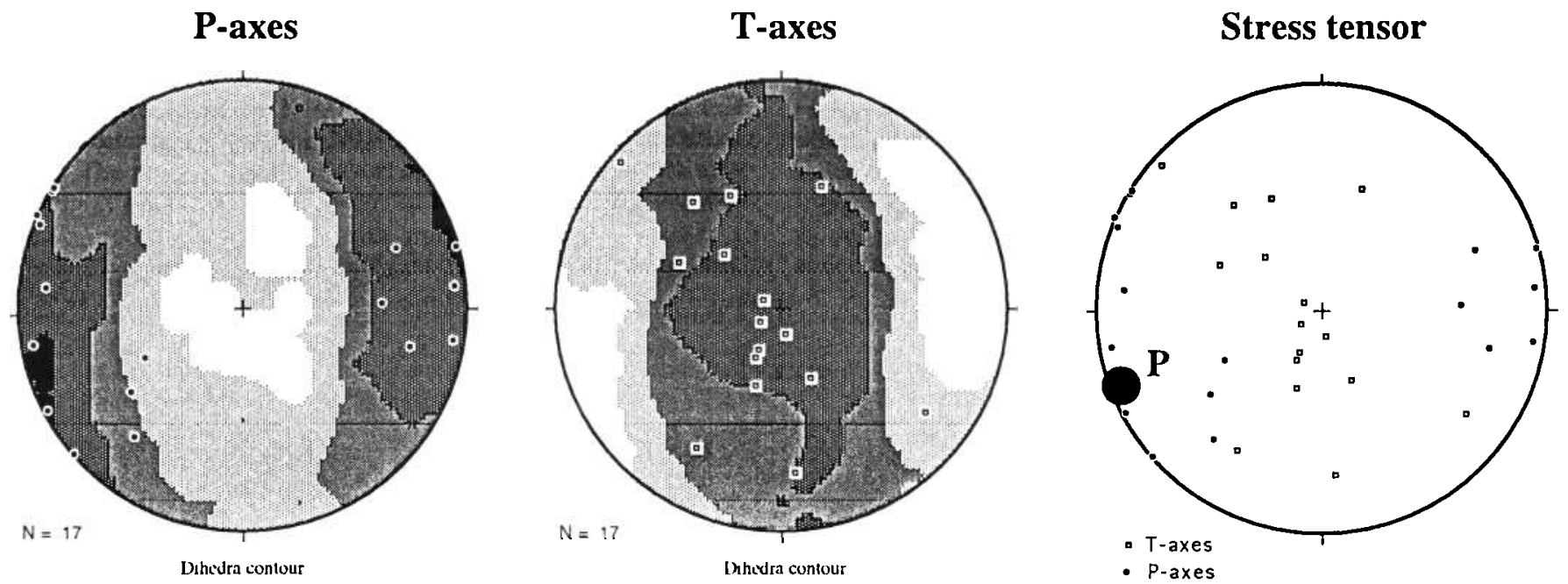

Fig. 6. $P$ and $T$ axes projection on stereodiagrams for 17 focal mechanisms (lower hemisphere). Seven focal mechanisms of the northem offshore earthquakes are not taken into account as they are not consistent with the other ones. Contours and grids are determined with the right dihedra method. 

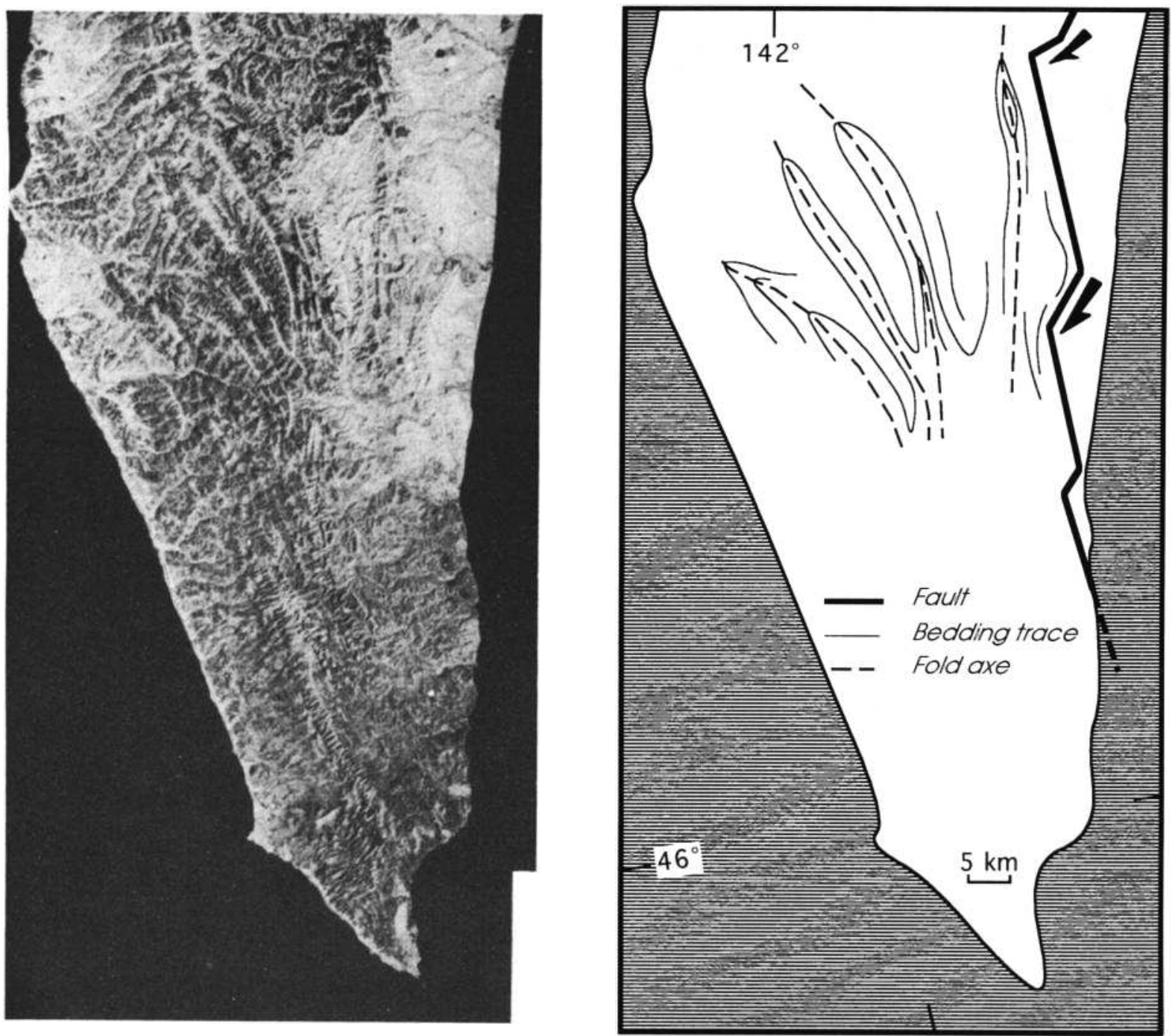

Fig. 7. Landsat image of the southwestem hom of Sakhalin (localized in Figure 3c) showing the clockwise curvature of the dextral en échelon fold axis in the vicinity of the Tym-Poronaysk fault.

northern Sakhalin are affected by similar N-NW trending folds [Rozhdestvensky, 1982, 1986]. The fold axes direction provides an east-northeast ( $\mathrm{N} 050^{\circ} \mathrm{E}$ to $\mathrm{N} 090^{\circ} \mathrm{E}$ ) trend of maximal horizontal stress, which is consistent with dextral motion along the Tym-Poronaysk fault, as well as the dextral en échelon pattern of the folds and their sigmoidal shape. In the field, the fault is a steep structure dipping sometimes to the east and to the west, always showing a reverse motion component. This is illustrated in Figure 8 with compressive structures, drag folds, and ramp and flat structures in Cretaceous formations along the fault. The overall structure, a N-S strike-slip fault with a reverse component associated with $\mathrm{N} 140^{\circ} \mathrm{E}$ to $\mathrm{N} 180^{\circ} \mathrm{E}$ trending folds, results from deformation in a transpressional regime along the $\mathrm{N}-\mathrm{S}$ discontinuity, with $\sigma_{H \max }=\sigma_{l}$ trending E-NE ( $\sigma_{H \max }$ is the maximal horizontal stress). The deformation is partitioned between pure compression along the $\mathrm{N} 160^{\circ} \mathrm{E}$ to $\mathrm{N} 180^{\circ} \mathrm{E}$ segments, and almost pure strike-slip shear along the $\mathrm{N} 010^{\circ} \mathrm{E}$ to $\mathrm{N} 045^{\circ} \mathrm{E}$ segments.

To the north, in the Aleksandrovsk-Sakhalinskiy area, two dextral en échelon Miocene basins trend NNE (Figure 3c). These basins are similar to those described below in the East Sakhalin Mountains and are consistent with Miocene dextral motion along the Tym-Poronaysk fault. As we will see later, the formation of these basins preceded their sublatitudinal shortening. Assuming that they formed parallel to $\sigma H \max$ as for extensional cracks, their present trends provide a direction for $\sigma_{H \text { max }}$ between $N 000^{\circ} \mathrm{E}$ and $\mathrm{N} 030^{\circ} \mathrm{E}$. Thus the maximal horizontal stress apparently rotated clockwise during the late Miocene from N000-N030 $\mathrm{E}$ to $\mathrm{N} 050-\mathrm{N} 090^{\circ} \mathrm{E}$. The significance of this apparent rotation will be discussed later.

Our interpretation of the SPOT images of the YuzhnoSakhalinsk region in the southern part of the fault (location in Figure $3 c$ ), is shown in Figure 9. The city is located in the central Quatemary depression (Figure $3 c$ ) bounded to the east by the Susunai metamorphic complex and to the west by the Tym-Poronaysk fault. The fault, parallel to bedding traces in its northern part, is twice shifted dextrally by NE trending segments in the vicinity of Yuzhno-Sakhalinsk and obliquely cut Cretaceous formations (Figure $3 c$ ). Dextral shear is also observed along a NE trending fault in the Susunai metamorphic complex to the east, where lineaments, probably representing the surface traces of the metamorphic foliation, are curved in a dextral sigmoid.

Figure 10 shows the interpretation of the two northern SPOT images along the fault (see location in Figure $3 c$ ). The sharpness of the Tym-Poronaysk fault is pronounced to the south, along the NE trending segment cutting through Lower 


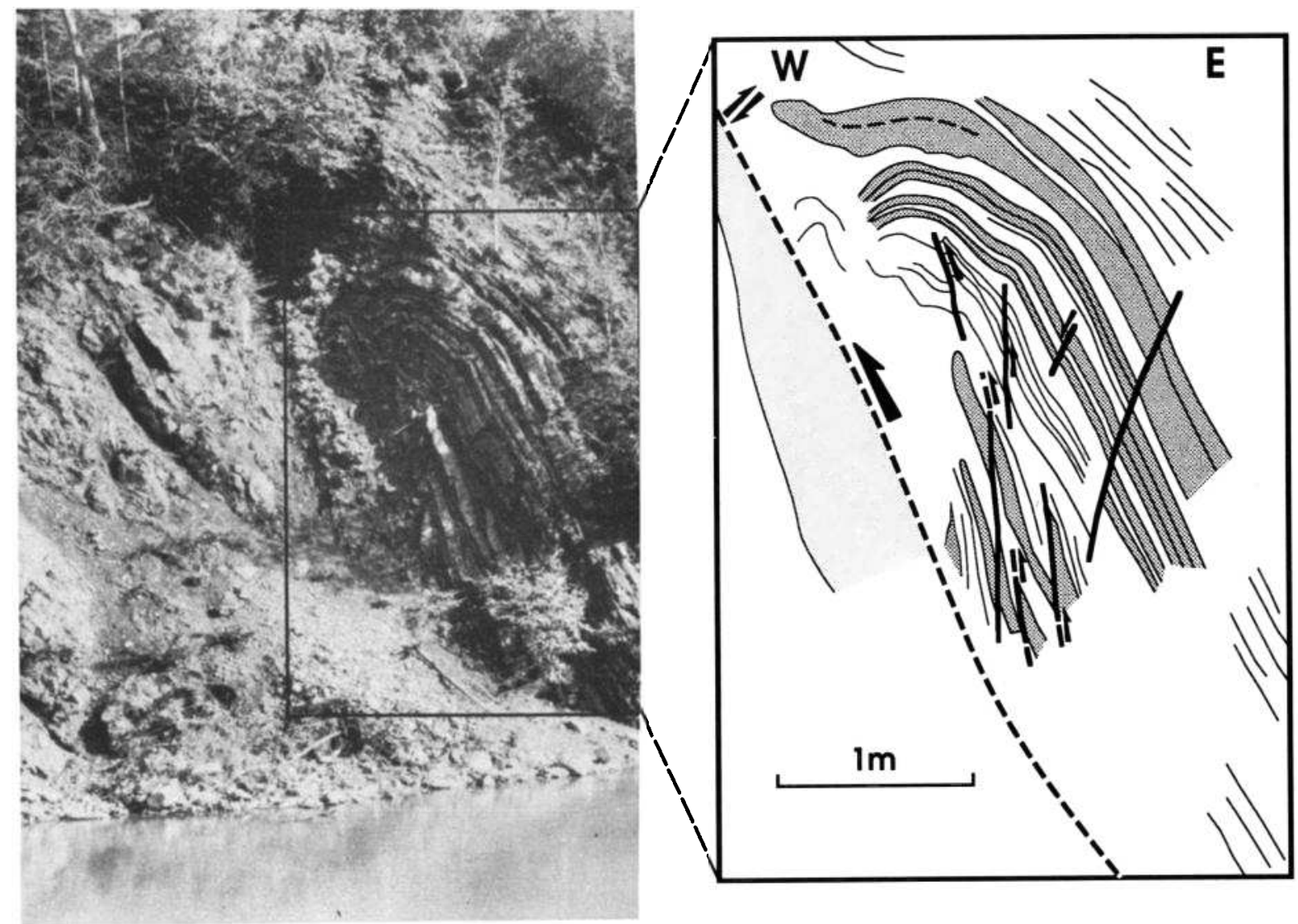

Fig. 8. Compressional structures (drag fold and ramp and flat structures) along the Tym-Poronaysk fault in Upper Cretaceous formations (central Sakhalin).

Late Cretaceous formations. The hanging wall to the west shows degraded triangular facets evidencing recent activity.

Small-scale field work was undertaken in the central region located on the east coast of the island, between Gastello and Vostochnyy (SPOT images detailed in Figures $11 a, 11 b$, and $11 c$, location on Figure $3 c$ ). On the SPOT images, the most prominent feature is the Santonian-Campanian cuesta marked by the thick terrigeneous Campanian deposits to the west (see Figure 11c). To the south this limit makes the Vostochnyy fold (NE trending axis) stand out on the images. To the west, the discordance of the Paleogene basal conglomerate (Figure $12 a$ ) onto Cretaceous strata is clearly observed on the images: the conglomerate cuts through the underlying Cretaceous bedding traces. Along the east coast the Tym-Poronaysk fault is a sharp feature particularly clear in its southern part where it divides the relief of Miocene terrigeneous and volcanic formations to the east from a depression filled with Cretaceous argilites (Bikov formation) to the west. As already noticed on the Landsat images, the Tym-Poronaysk fault consists of long roughly N-S segments dextrally shifted by short NE trending segments. Evidence for dextral Miocene motion along the fault is especially remarkable in the north where three en échelon folds in Miocene formations are strained by dextral shear. A similar fold in the Neogene Kholmsk formation is shown in Figure $12 b$ outcroping along the coast line, south of Yuzhno-Sakhalinsk. Figure 13 shows two cross sections through the Tym-Poronaysk fault (see location of the cross sections in Figure 11c): the folds close to the fault evidence the transverse shortening associated with strike-slip motion (see also Figure $10 c$ showing vertical Miocene sedimentary beds). The upper Miocene and Pliocene deposits are weakly folded and the younger part of the section (the late Miocene-
Early Pliocene Manuyama formation) is even less folded with limbs dipping not more than $20^{\circ}$. Thus these folds experienced a continuous deformation during the Miocene and the Pliocene. Three Quaternary terraces are superimposed on the west coast of the island, the highest one (probably 500,000 years old by analogy with Hokkaido) is about $500 \mathrm{~m}$ high, and there is only one low terrace or no terrace at all on the east coast. This is an indicator of relative uplift of the west coast with respect to the east coast. The Tym-Poronaysk fault is likely to localize relative motion between the east and the west coasts, which would imply an intense Quatemary activity with a high reverse component of motion [Zakharov and Yakushko, 1972]. However, it was not possible to observe whether the Quaternary marine terraces are folded or not. In some places the Tym-Poronaysk fault splits in several parallel segments and could be the surface manifestation of a deep compressional flower structure. Volcanic rocks mapped in Figure $11 b$ were emplaced during the Miocene as dykes and sills in the vicinity of the fault, with a NNE trending direction slightly oblique to the fault, compatible with dextral shear along it. Large sills in Cretaceous formations are also mapped in Figure 11a. These sills make the topographic crests and determine the geometry of the hydrographic network. One such sill is shown in Figure $12 c$ in Miocene deposits.

Volcanic rocks recorded well the brittle deformation and are good candidates for stress orientation measurements along the Tym-Poronaysk fault in both Cretaceous and Miocene formations. Four stereograms used to calculate the paleostress field directions plotted in Figure $12 c$ are shown in Figure 14. The tensor analysis follows the method developed by Angelier [1984]. In the field we mostly observed compatible strike-slip and reverse faults. The direction of $\sigma_{l}$ is bracketed between 


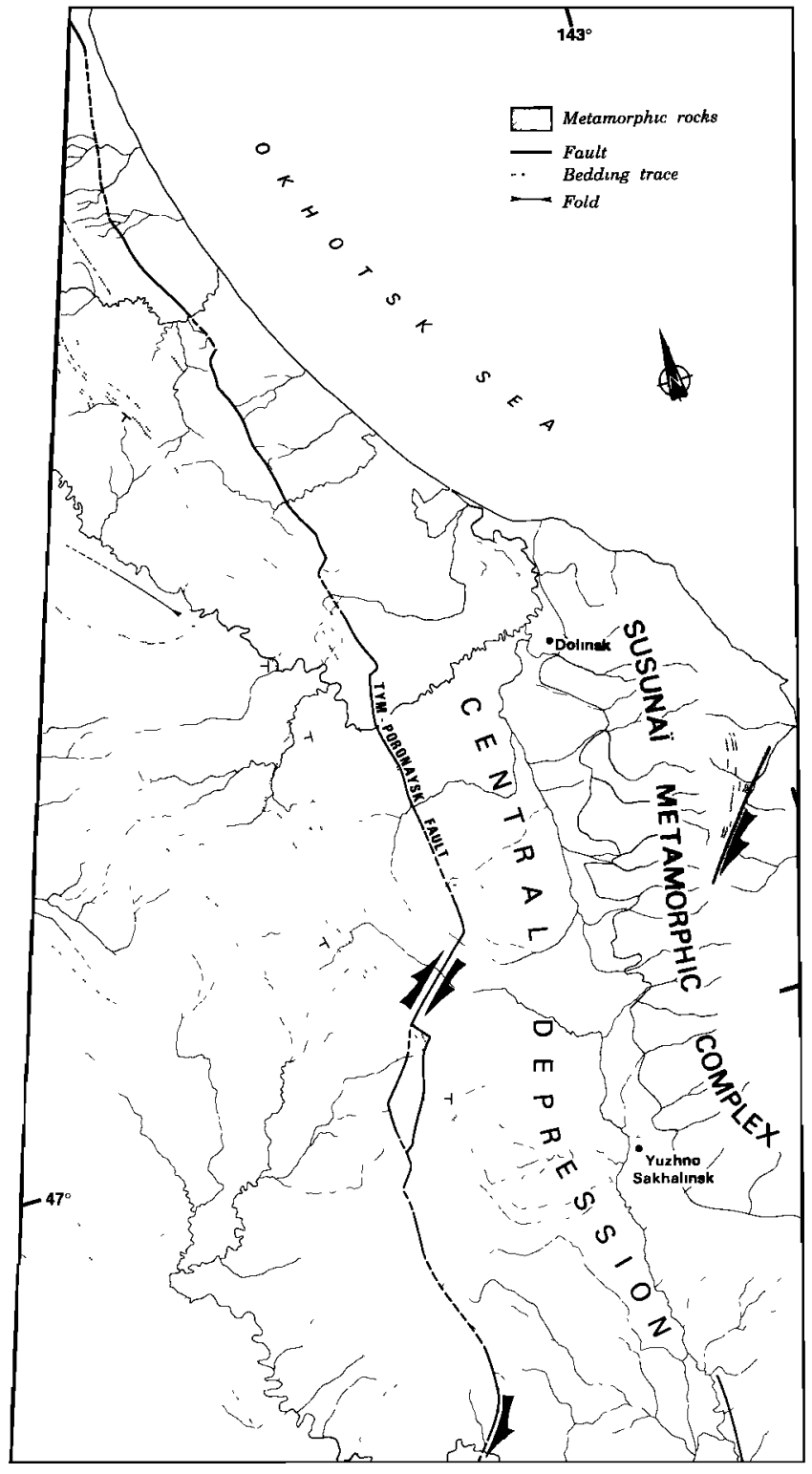

Fig. 9. Structural interpretation of a mosaic of two SPOT images of the Yuzhno-Sakhalinsk region along the Tym-Poronaysk fault (localized in Figure 3c).

$\mathrm{N} 050^{\circ} \mathrm{E}$ and $\mathrm{N} 090^{\circ} \mathrm{E}$ and it is always perpendicular to the fold axes. We therefore assume that the measured stress field is associated with folding. The sites TPF7, TPF8 and TPF9 are located on an almost pure strike-slip segment of the fault, along which the fold axes are curved and suffered at least a $30^{\circ}$ clockwise rotation (Figures $12 c$ ). The $\sigma_{1}$ rotated clockwise with the fold axes near the fault. Thus the true trend of $\sigma_{I}$ associated with folding is likely to be bracketed between $\mathrm{N} 020^{\circ} \mathrm{E}$ and $\mathrm{N} 060^{\circ} \mathrm{E}$. The superposition of two distinct stress fields discernable chronologically was seldom observed. When observed, it showed that $\sigma_{l}$ was always horizontal and trended first E-W and secondly NE-SW, which can be accommodated by a progressive clockwise rotation of structures under a single stress field with $\sigma_{l}$ trending NE-SW. This NE-SW trend is consistent with dextral strike-slip motion along the Tym-Poronaysk fault.

Paleostress fields inferred from fault measurements undertaken in other parts of the island are plotted in Figure $3 b$ and the corresponding stereo plots are shown in Figure 15. We first focus on the southeast peninsula of the island northeast of Aniwa bay where faults were measured in Jurassic, Cretaceous and Paleogene rocks (see geological map in Figure $3 c$ ). Two sites (T3 and T5) have recorded two successive episodes with roughly perpendicular $\sigma_{l}$ (site $\mathrm{T} 4$ also recorded two successive episodes but it is disturbed by the emplacement of a Paleogene granite in its vicinity). No obvious chronology has been observed in the field; the chronology

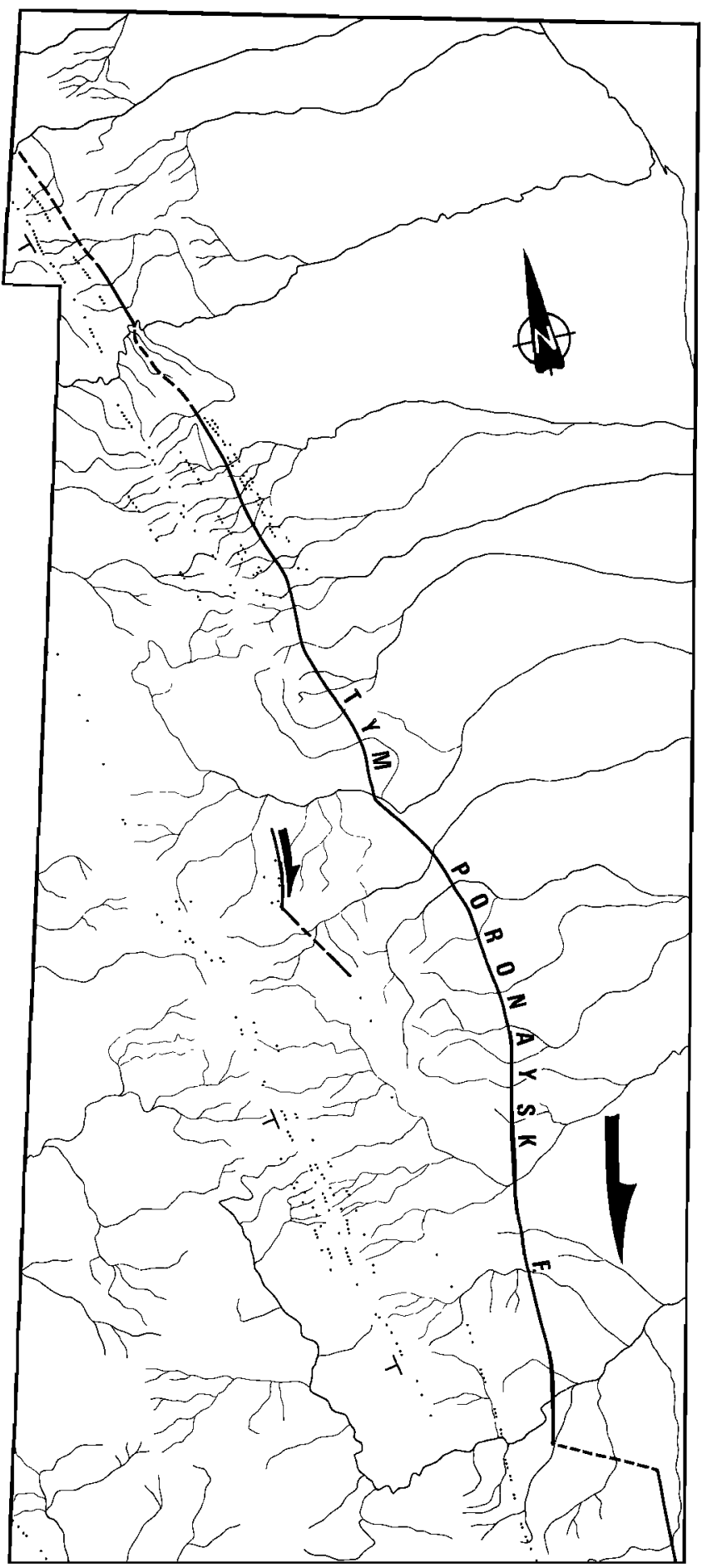

Fig. 10. Structural interpretation of a mosaic of two SPOT images along the Tym-Poronaysk fault (northem region localized in Figure $3 c$ ). Same legend as figure $9 . \mathrm{F}$ is fault. 


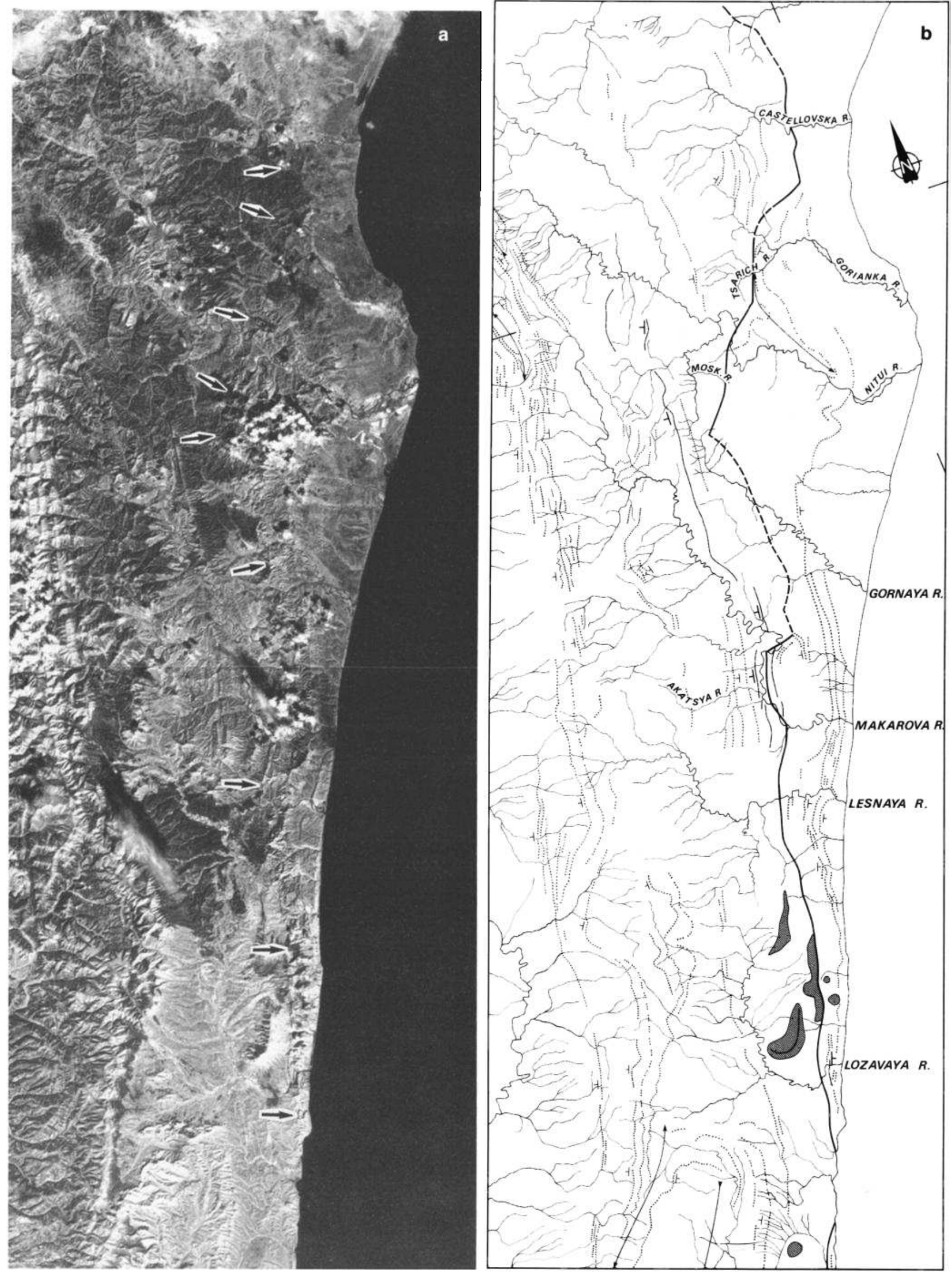

Fig. 11. (a) Mosaic of two SPOT images along the Tym-Poronaysk fault (central region localized in Figure $3 c$ ) and (b) structural interpretation. Same legend as Figure 9 . Thick lines are fault traces and the main sills are mapped with thin lines. The arrows on the images show the Tym-Poronaysk fault trace. (c) Geological map of the central region after K. F. Sergeyev (unpublished data, 1980) and our new observations. Key shows (1) Maruyama formation and upper Pliocene-Quatemary deposits, (2) Verkneduyska formation, (3) Tcheckhov formation, (4) Kholmsk formation, (5) Gastello formation, (6) Paleogene basal deposits, (7) (8), and (9) Bikov suite, (10) Miocene volcanics, (11) mud volcano, (12) fault and suspected fault (dashed line), (13) fold axis (syncline and anticline, respectively), (14) geological contour and suspected geological contour (dashed line), (15) paleo-stress field direction. The Santonian-Campanian cuesta is shown as the boundary between formations 7 and 8 . 


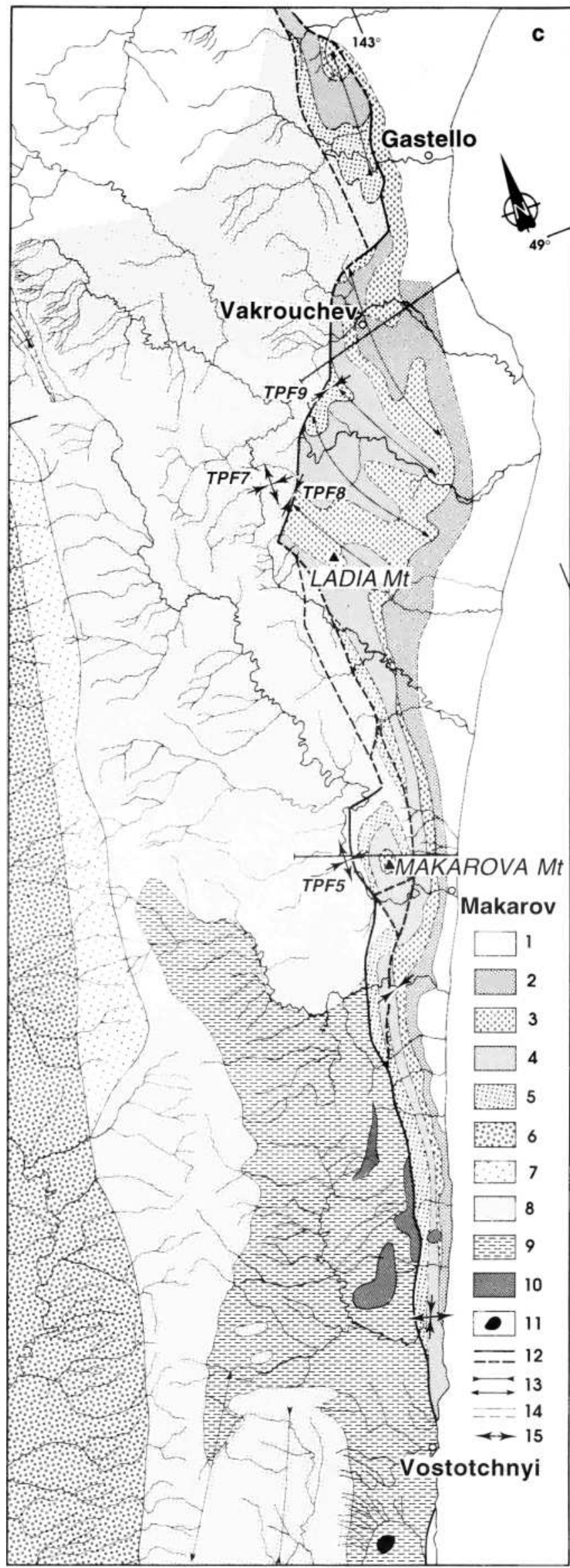

Fig. 11. (continued) given in Figure $3 c$ is based on the study area being analogous to NE Japan [Jolivet et al., 1990]. Figure 15 illustrates phase separation for the three sites T3, T4 and T5. Phase 1 has $\sigma_{1}$ trending $N 020^{\circ} \mathrm{E}$ in good agreement with most of the sites of the peninsula, and also with direction of $\sigma_{1}$ determined in the central region (see above). If we generalize these observations to the whole island, it is possible to interpret all the computed paleo-stress-directions in one single stress system with horizontal $\sigma_{l}$ trending NE-SW, and with local rotations along the Tym-Poronaysk fault. Phase 2 with $\sigma_{l}$ roughly E-W can be related either to late sublatitudinal shortening as observed in Hokkaido [Jolivet et al., 1990] or to local rotations as observed along the Tym-Poronaysk fault.

\section{Geometry of the Neogene Strike-Slip Deformation in the East} Sakhalin Mountains

In the East Sakhalin Mountains three parallel submeridian en- échelon faults cut through the Paleozoic and Mesozoic basement (Figures $3 b$ and $3 c$ ): from west to east they are the Central, Pribrezhnaya (coastal) and Liman (estuarine) faults [Rozhdestvensky, 1982]. These faults are well expressed on the Landsat images in their northern parts (see a detail of the Landsat mosaic in Figure 16) as they put into contact contrasted lithological formations, a high block to the west made of Mesozoic rocks cut by deep valleys, and a low one to the east made of Neogene deposits with smooth topography.

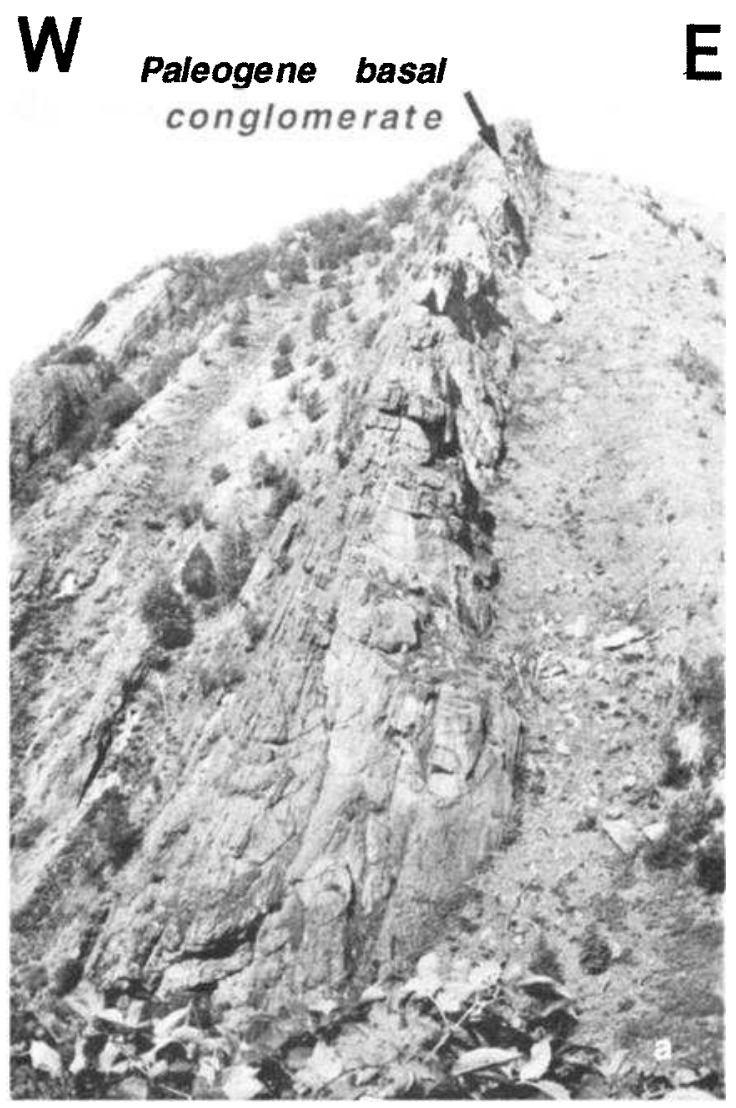

Fig 12. (a) Paleogene basal conglomerate on the E-W road to Boshnyakovo (central Sakhalin), lying unconformably onto Upper Cretaceous formations (to the east). The thickness of the conglomerate is variable and reaches $600 \mathrm{~m}$ in some places. (b) Distupted fold in Neogene Kholmsk formation south of Yuzhno-Sakhalinsk. (c) Sill in almost verticalized Miocene sedimentary beds along the Tym-Poronaysk fault in the Lozovaya river valley (mapped in Figure $11 \mathrm{~b}$ ). Cooling joints are perpendicular to the stratification. 

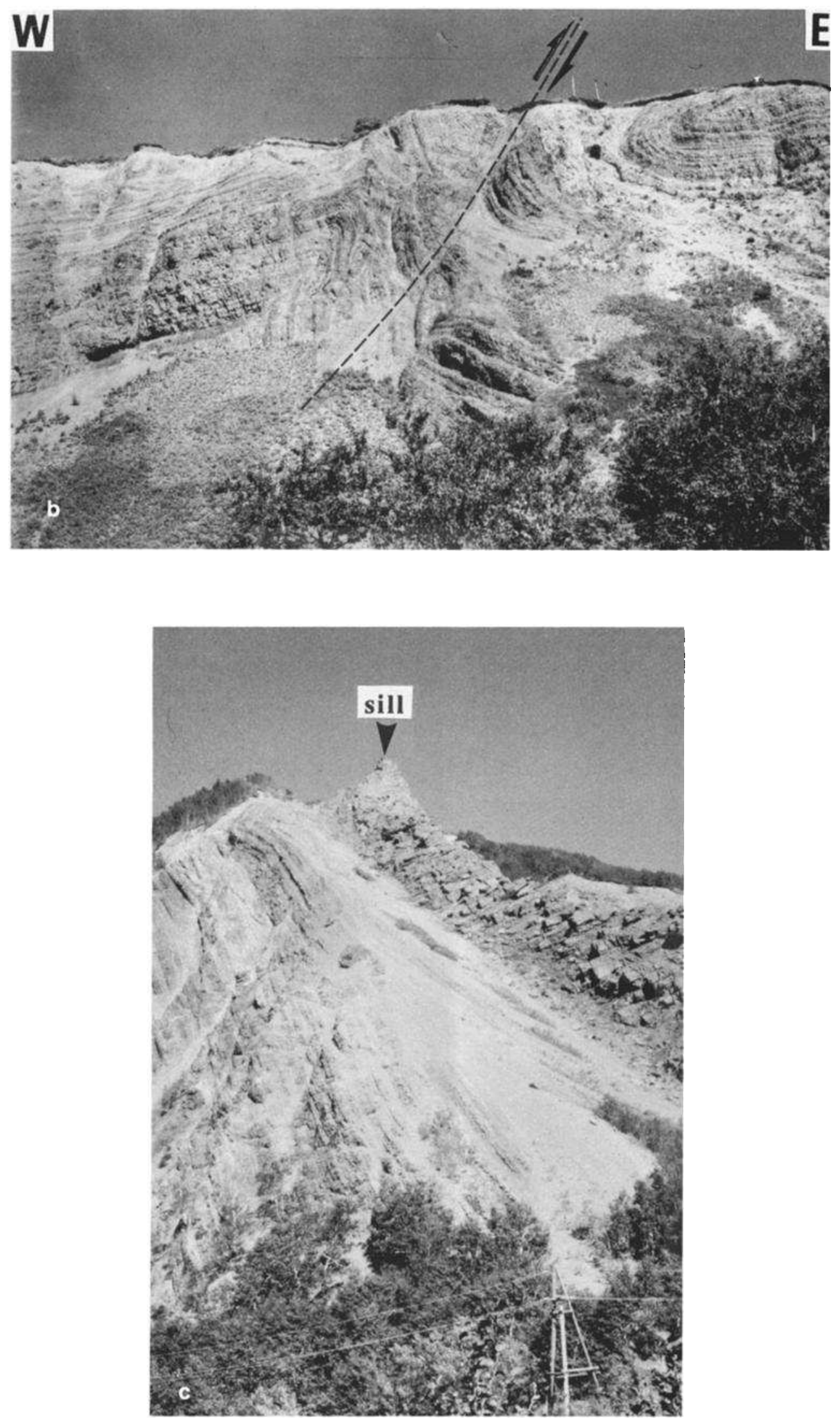

Fig. 12. (continued) 


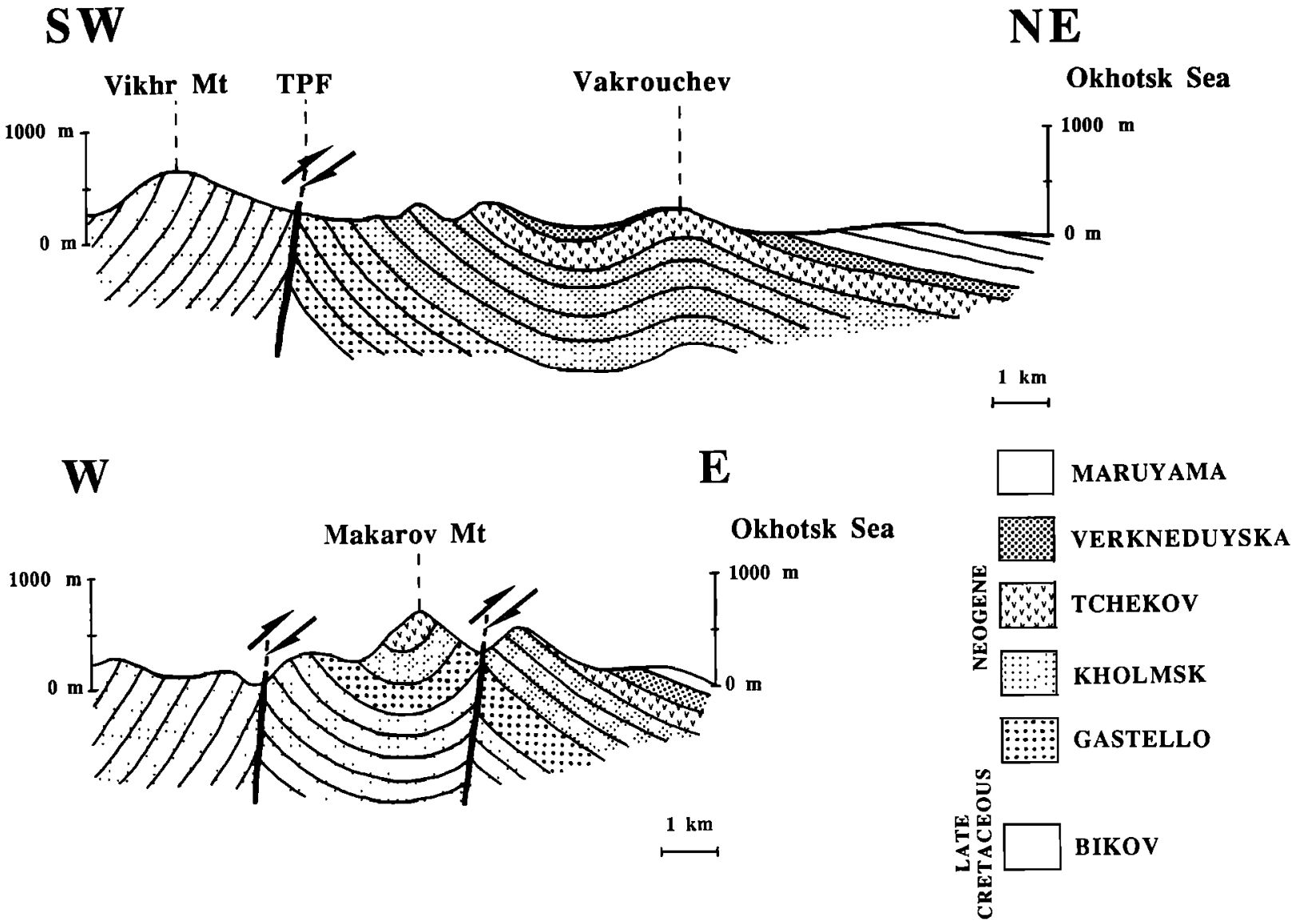

Fig. 13. Cross-sections across the Tym-Poronaysk fault (localized in Figure 11c). TPF is Tym-Poronaysk fault.

The faults are indeed bordered to the east by narrow basins with a NNE trend, filled with Miocene and Pliocene deposits overlying unconformably the Paleozoic and Mesozoic basement [Rozhdestvensky, 1982]. The present trends of the basins $\left(\mathrm{N} 000^{\circ} \mathrm{E}\right.$ to $\left.\mathrm{N} 030^{\circ} \mathrm{E}\right)$, assumed to be parallel to the maximal horizontal stress direction, and their dextral en échelon pattern are consistent with dextral strike-slip motion along N-S faults. A Neogene pull-apart basin along the Central fault is also an indicator of dextral motion, and to the south the sigmoidal shape of the Mesozoic crests between the Pribrezhnaya and the Liman fault supports dextral shear along these faults. The three faults therefore experienced dextral strike-slip motion with a normal component in Neogene time. An evaluation of the displacement along the Central fault is given by the $25-\mathrm{km}$ offset of the metamorphic complex in the southern part of the fault (Figure $3 c$ ). The Langeri graben (Figure 16) is filled with Mio-Pliocene formations up to $600 \mathrm{~m}$ thick lying unconformably either on Paleozoic or Mesozoic rocks [Rozhdestvensky, 1982]; the Miocene deposits are folded and stand almost vertically on the east side of the basin. A late sub-latitudinal shortening thus affected the Miocene basin. Similar observations are made along the southem coast of the Aniva peninsula to the south, where the Mesozoic basement was thrusted eastward over Paleogene basins folded into synclines (cross sections of Melnikov and Rozhdestvensky [1989], and Rikhter [1986]).

North of the East Sakhalin Mountains, the submeridian Gyrgylan'i-Ossoy, Ekhabi-Pil'tun and Okha faults continue the above described structures until the Schmidt Peninsula through Neogene formations. We observed on the Landsat images that the northem part of the Gyrgylan'i-Ossoy fault shifts dextrally a ridge for about $10 \mathrm{~km}$ (Figure $3 b$ ). According to Rozhdestvensky [1982], en échelon folds with sigmoidal bends evidence dextral motion along these faults. In the Schmidt Peninsula the Cretaceous-Neogene contact is dextrally offset by a strike-slip fault for $5.5 \mathrm{~km}$, and another strike-slip fault cut through Neogene sediments with a displacement of up to $7 \mathrm{~km}$ [Rozhdestvensky, 1982]. A summation of the strike-slip offsets of faults from the East Sakhalin Mountains to the Schmidt peninsula therefore gives a minimum value of dextral N-S relative motion of about 50 $\mathrm{km}$ since Miocene time.

\section{Discussion: Progressive Strike-Slip Deformation From} Miocene to Present

The observations made at all scales reveal the juxtaposition and succession in time and space of pure strikeslip structures, pure compressional structures, and extensional structures. At island scales, the western side of the TymPoronaysk fault is characterized by en échelon folds and the fault itself has a thrust component which indicates a transpressional regime along $600 \mathrm{~km}$ from south to north. While the Upper Cretaceous to Neogene sediments on the west side of the fault displays a distributed deformation symptomatic of a relatively soft medium, the more competent Mesozoic basement on the eastern side of the fault displays en échelon narrow basins localized along strike-slip faults (in the East Sakhalin Mountains), which had been in turns folded showing an apparent rotation of $\sigma_{l}$. Small-scale observations shows that compression is always perpendicular to the fold axes and that the E-W compression seen in the microtectonic 

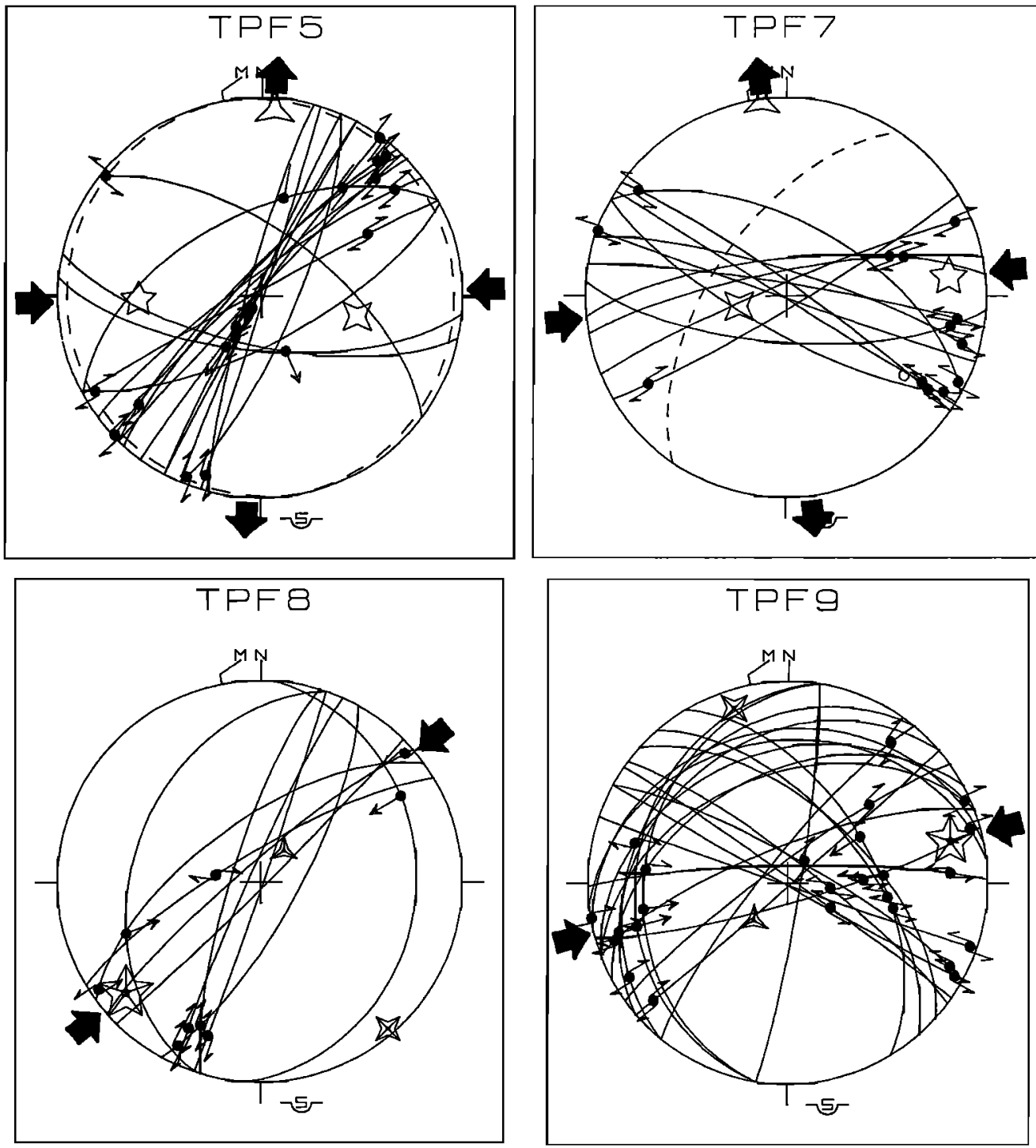

Fig. 14. Fault set stereodiagrams (Schmidt projection, lower hemisphere) and deduced paleostress field directions for four sites plotted in Figure $12 b$. Dashed lines represent bedding planes. Three-branch star is $\sigma_{3}$. Four-branch star is $\sigma_{2}$. Five-branch star is $\sigma_{1}\left(\sigma_{1}>\sigma_{2}>\sigma_{3}\right)$.

analyses is the result of clockwise rotations close to the TymPoronaysk fault. Thus at this scale, only one stress regime is required. It is possible to reach the same conclusion at the scale of the island with large-scale structures.

The overall structure of the East Sakhalin Mountains can be described as a domino system in a shear zone between two master faults, the Tym-Poronaysk fault to the west and an offshore fault observed on seismic data along the northeast coast of Sakhalin to the east [Gnibidenko and Svarichevsky, 1984; Gnibidenko, 1985], the Central, Pribrezhnaya, and Liman faults being cross faults which bound crustal blocks (Figure 17). Such geometry implies block rotations about vertical axes [Ron et al., 1984; Nur et al., 1986; Scotti et al., 1991]. Assuming that the cross faults appear first as extensional cracks parallel to $\sigma_{H \text { max }}$ and are later rotated, the sense of rotation depends upon the sign of the stress tensor component perpendicular to the plane of the master faults. An overall transtensional stress field would lead to a widening of the shear zone and favors clockwise rotation of blocks accommodated by sinistral motion along the cross faults.
Extra space in the shear zone would be accommodated by the formation of grabens along the cross faults. However, if transpression prevails, the shear zone tends to narrow and counterclockwise rotations will be accommodated by dextral motion along the cross faults. E-W shortening will be taken up by counterclockwise rotations of the blocks and compressional structures along their borders. Applying this model to the East Sakhalin Mountains where the stress regime is transpressional and the cross faults are dextral, we should expect counterclockwise rotations of the dominos.

The evolution of the East Sakhalin Mountains can be explained as follows: the narrow basins first formed along the cross faults which were parallel to the maximum horizontal stress and then later progressively rotated in a counterclockwise manner. The trend of the basins thus becomes oblique to the maximum horizontal stress and they were subjected to shortening and folding. Takeuchi et al. [1992] recently presented paleomagnetic results from Hokkaido and southern Sakhalin, including several sites on the westem side of the Tym-Poronaysk fault. They obtained 

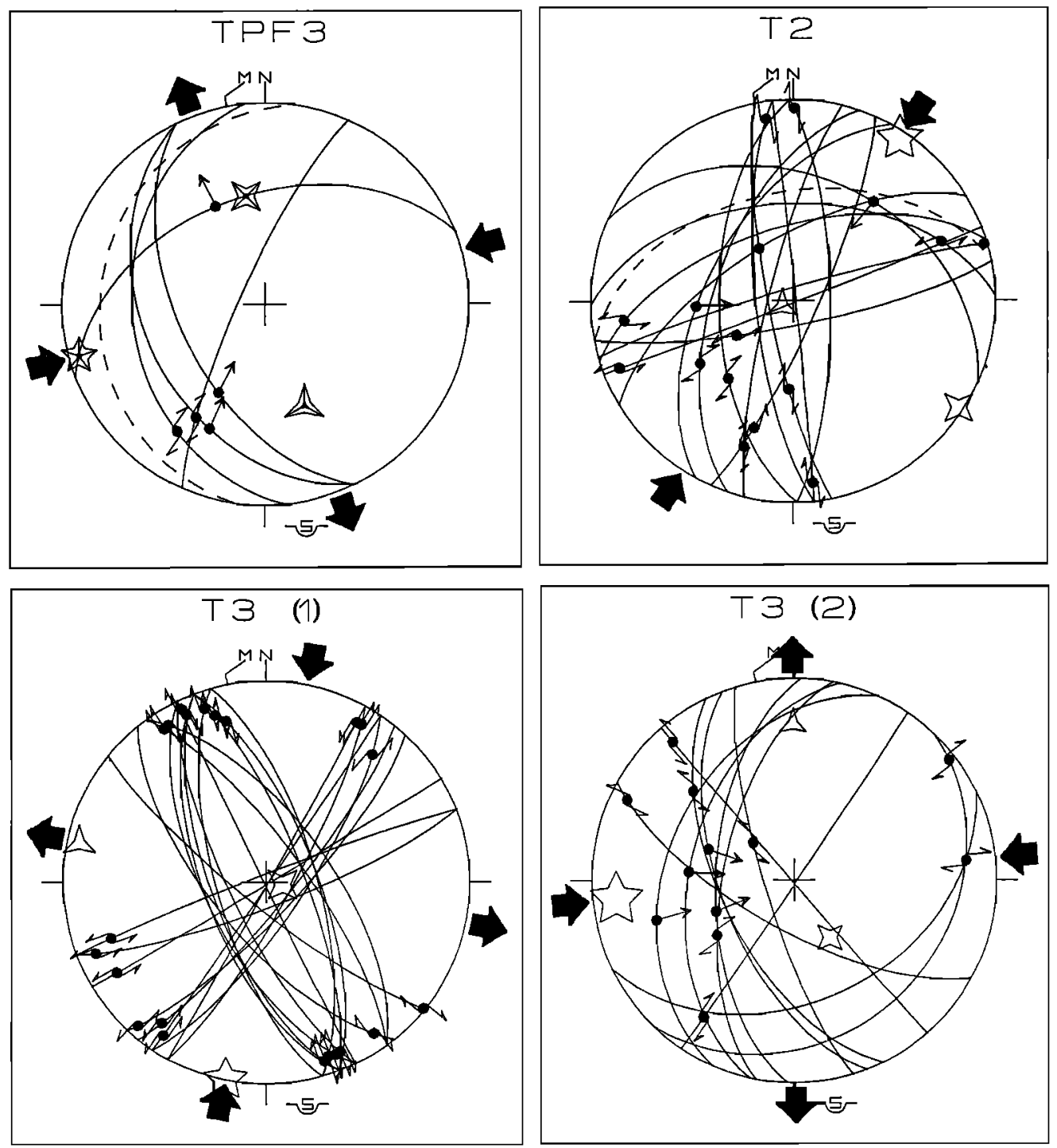

Fig. 15. Fault set stereodiagrams (lower hemisphere) and deduced paleostress field directions for sites plotted in Figure $3 b$. Two successive stress fields are observed on sites T3, T4, and T5.

Middle to Late Miocene dextral rotations, compatible with the progressive dextral shear of the fold axes along the fault. They unfortunately have no data from the East Sakhalin Mountains, so the block model there cannot be tested with the paleomagnetic results obtained so far. The expected counterclockwise rotations are however small and might not be easily detected.

Figure 17 shows the precise geometry imposed by this model. Figure $17 a$ shows the simplified fault pattern in Sakhalin, which is isolated from the coast lines in Figure $17 b$. The continuity of geological structures in western Sakhalin shows that this region behaved as a single elongated block between the West Sakhalin fault and the Tym-Poronaysk fault. Continuous strain within the block was accommodated by en échelon folds leading to oblique shortening. In the East Sakahlin mountains, however, the basement was cut by several parallel faults and was divided into several dominos which we predict have rotated counterclockwise. Figure $17 c$ is a simplification of the fault pattem with a block model. The EW shortening coeval with dextral strike-slip involves a component of thrusting along the blocks boundaries, since the total width of the shear zone decreases. One can see that the counterclockwise rotation of blocks along the dextral cross faults can lead to the distribution of pure strike-slip segments and mostly compressional segments actually observed along the Tym-Poronaysk fault. This geometry can be obtained provided that some of the cross faults can be connected to some of the dextral offsets along the TymPoronaysk fault through the basement under the Quaternary depression as shown in Figure $17 b$.

The observed clockwise rotations of fold axes caused by dextral simple shear along the Tym-Poronaysi fault can explain the E-W direction of compression deduced from fault set analysis: $\sigma_{I}$ was initially NE-trending and has been rotated with the rocks. The block model with counterclockwise rotations in the East Sakhalin Mountains can explain the apparent succession of tectonic stages (basins formation followed by transverse shortening) in the single transpressional stress field [Scotti et al., 1991]. This model integrates in a single stage a succession of superimposed structures of various style and explains the geometry of the Tym-Poronaysk fault, but it still needs to be tested with paleomagnetic data. However, we cannot eliminate the possibility of a change in stress conditions from $\sigma_{l}$ trending NE-SW to nearly E-W (see Figure 2). 

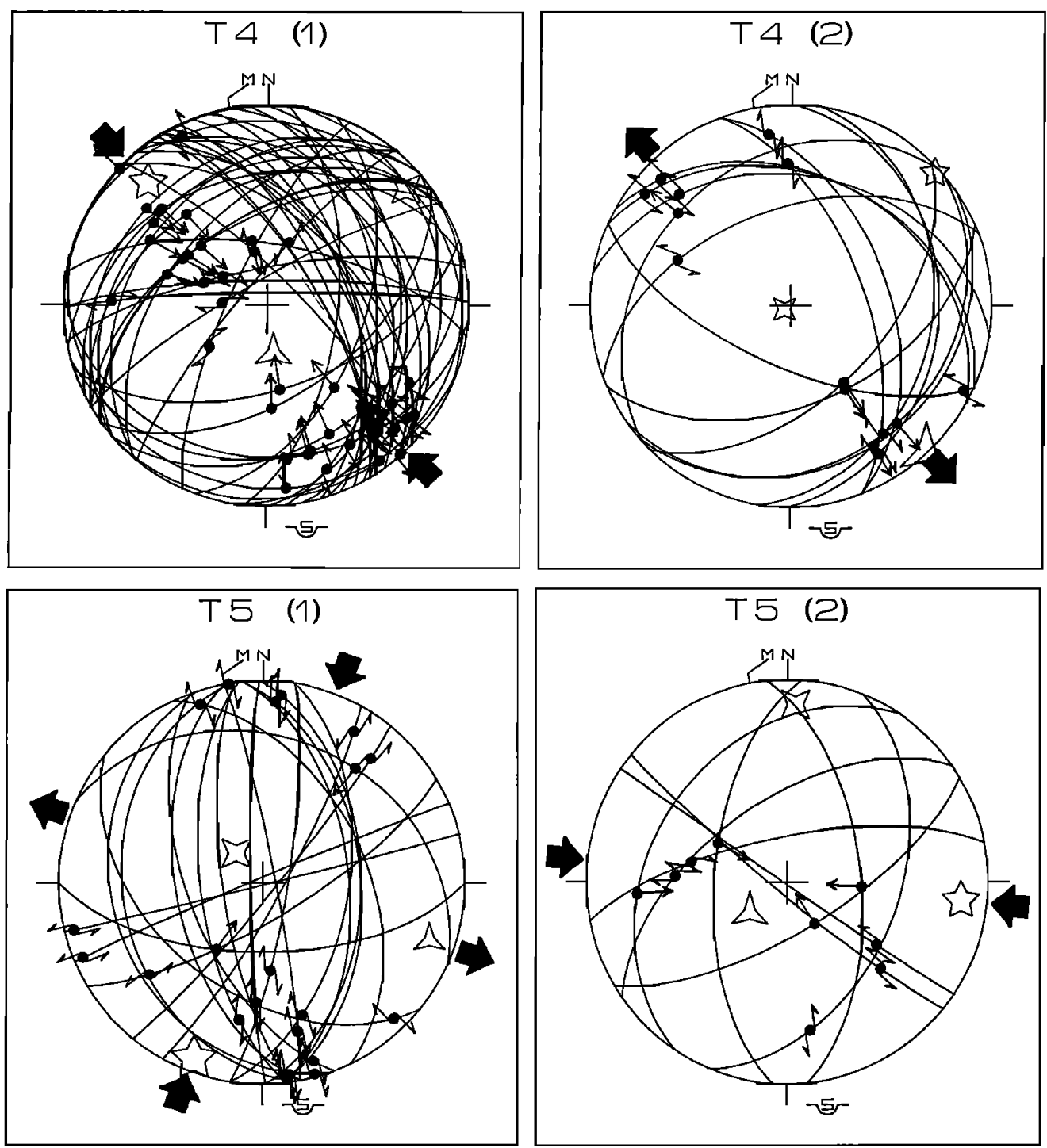

Fig. 15. (continued)

\section{Transtensional Deformation in Noto Peninsula and Yatsuo BASIN}

We have described Sakhalin Island as a Neogene N-S dextral strike-slip zone. This continues to the south in the Hiddaka Mountains (Hokkaido) reworking a major Mesozoic suture zone that localized part of the strain during the Cenozoic [Kimura et al., 1983]. Strike-slip ductile deformation in high-temperature conditions [Jolivet and Miyashita, 1985] during late Oligocene and early Miocene is associated with en échelon folds and thrusts in the upper brittle crust [Jolivet and Huchon, 1989]. Fault set analysis in lower and middle Miocene formations provides a direction of horizontal compression compatible with folding that trends NE-SW. The same dextral transpressional stress field therefore characterizes Sakhalin and Hokkaido during the early and middle Miocene.

Further south Miocene strike-slip extends along the eastem margin of the Japan Sea. It is distributed in a transition zone between the oceanic crust of the Japan Sea basin and the continental crust of the Japan arc. It is expressed offshore by dextral en échelon basins with a NNE trend [Lallemand and Jolivet, 1985; Tamaki, 1988; Jolivet et al., 1991] and onland by the dextral transtensional deformation described by $O t s u k i$ [1989, 1990] and Jolivet et al. [1991], distributed all along the west coast of NE Honshu down to Sado island to the south. Yamaji [1990] described basins in the Uetsu district (along the west coast of NE Honshu) formed between 18 and $15 \mathrm{Ma}$ with the same dextral en echelon pattern. To the south the Tanakura Tectonic Line (Figure 2) localized part of the dextral motion during the Miocene [Otsuki and Ehiro, 1978; Koshiya, 1986].

The transition from transpression to transtension is observed at the latitude of southwest Hokkaido. In order to see the transition between the dextral shear zone and the southern extensional margin of the Japan Sea [Tamaki, 1988], we studied the brittle deformation in Noto peninsula and Yatsuo basin (Figure 18) at the southeast corner of the Japan Sea (see location in Figure 1). Volcanic and pyroclastic rocks of Miocene age observed in Noto peninsula and Yatsuo basin lay directly on the Upper Cretaceous basement. Upper Miocene formations did not record any significant brittle deformation. Lower and middle Miocene formations are affected by conjugate strike-slip faults associated with compatible normal faults: fault sets analysis provides a direction of maximal horizontal compression trending $\mathrm{N} 030^{\circ} \mathrm{E}$ associated with a perpendicular extension (Figure 18 ). On a regional scale, the 

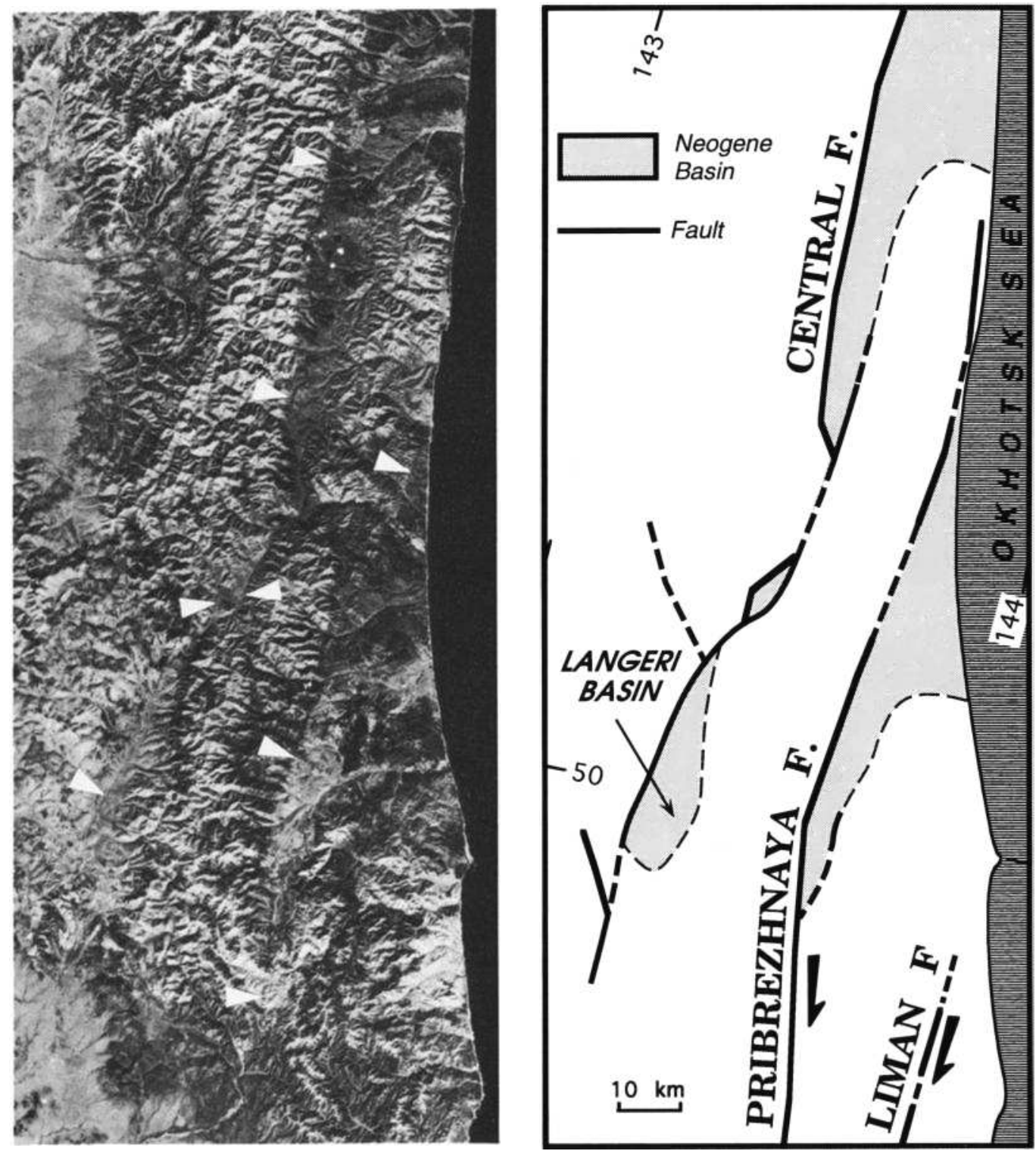

Fig. 16. Detail of the Landsat image of the East Sakhalin Mountains showing three parallel faults bounding Neogene basins.

Yatsuo basin is bordered to the east and to the south by large normal faults that probably have some strike-slip component in this transtensional context. The middle Miocene transtensional deformation corresponds to a late stage of opening of the Japan Sea.

Our results are in agreement with previously published paleostress fields [Otsuki, 1989, 1990; Jolivet et al., 1991] determined along the eastern margin of the Japan Sea from northern Honshu to Sado island: we observed in Noto peninsula and Yatsuo basin the same association of strike-slip and normal faults as in Sado, with similar principal stress directions. The same transtensional conditions prevailed all along the margin during opening of the Japan Sea and the deformation of the strike-slip margin continued during oceanic accretion.

\section{Discussion AND CoNCLUSIONS}

Nakamura and Uyeda [1980] showed that stress regime evolved in NE Japan during late Miocene from an extensional regime with $\sigma_{H \max }=\sigma_{2}$ trending NNE to a compressional regime with $\sigma_{H \max }=\sigma_{1}$ trending E-W. The late E-W compression is recorded in late Miocene and Pliocene rocks [Yamagishi and Watanabe, 1986; Jolivet and Huchon, 1989]: it is related to an uplift of westem northeast Japan since $10 \mathrm{Ma}$ [Sugi et al., 1983; Jolivet and Tamaki, 1992]. The offshore Miocene extensional structures have been reworked as compressional ones [Tamaki and Honza, 1984; Tamaki, 1988], and Tamaki et al. [1992] showed that thrusting and convergence along the eastern margin began $1.8 \mathrm{Ma}$ ago. The margin is seismically active and focal mechanisms of earthquakes indicate compression along N-S reverse faults [Fukao and Furumoto, 1975; Tamaki, 1988](see also Figure 3 of Jolivet et al. [1992]).

The stress field and the associated deformation evolved along the strike-slip zone (Figure 2). In early and middle Miocene time the stress field was transpressional to the north in Sakhalin and Hokkaido, and transtensional to the south where the Japan Sea opened behind the Pacific subduction zone. During the late Miocene the stress orientation changed: in the south $\sigma H_{\max }$ rotated clockwise from NE-SW to E-W (we have seen before that we do not necessarily need a rotation of 


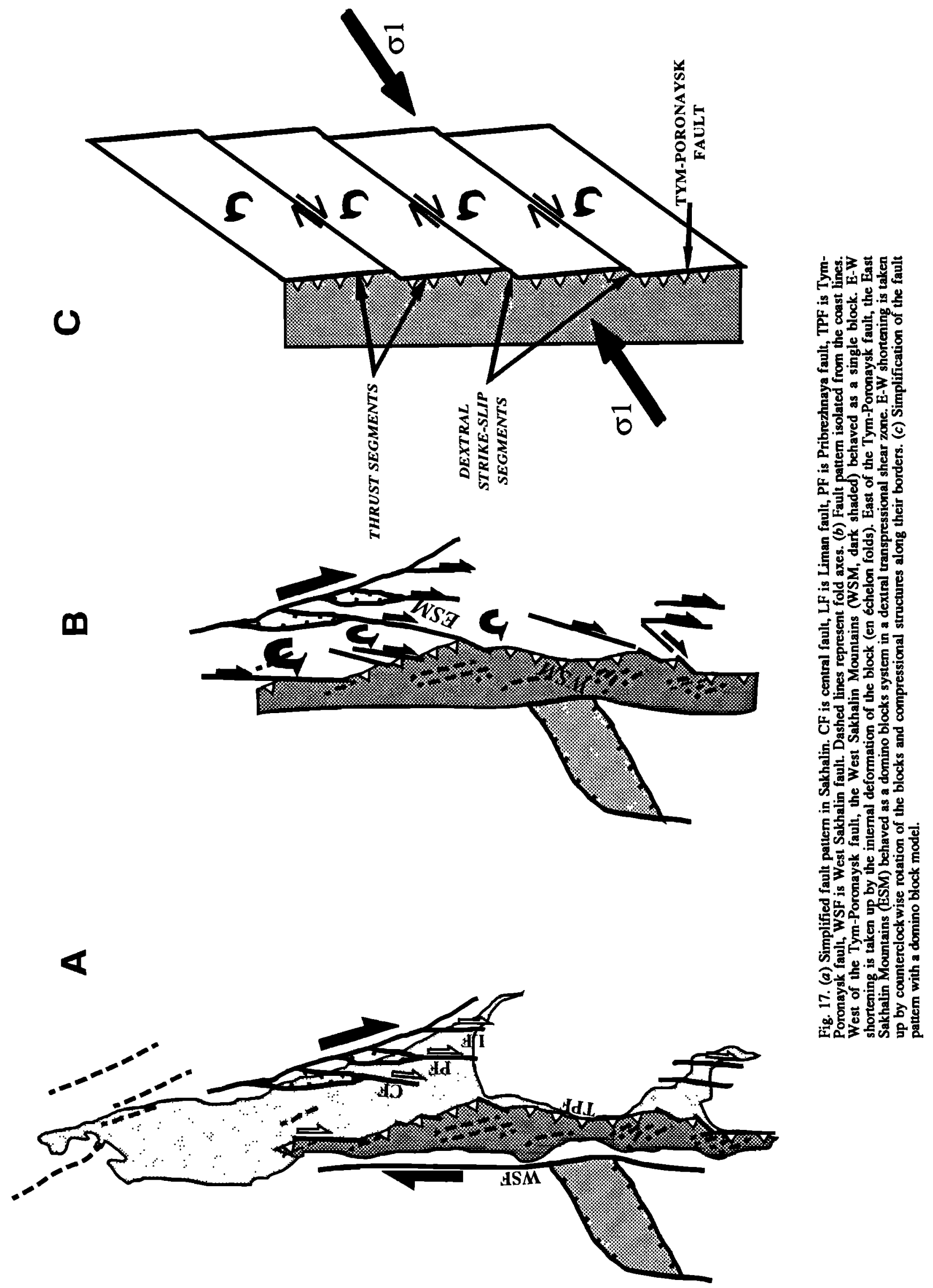




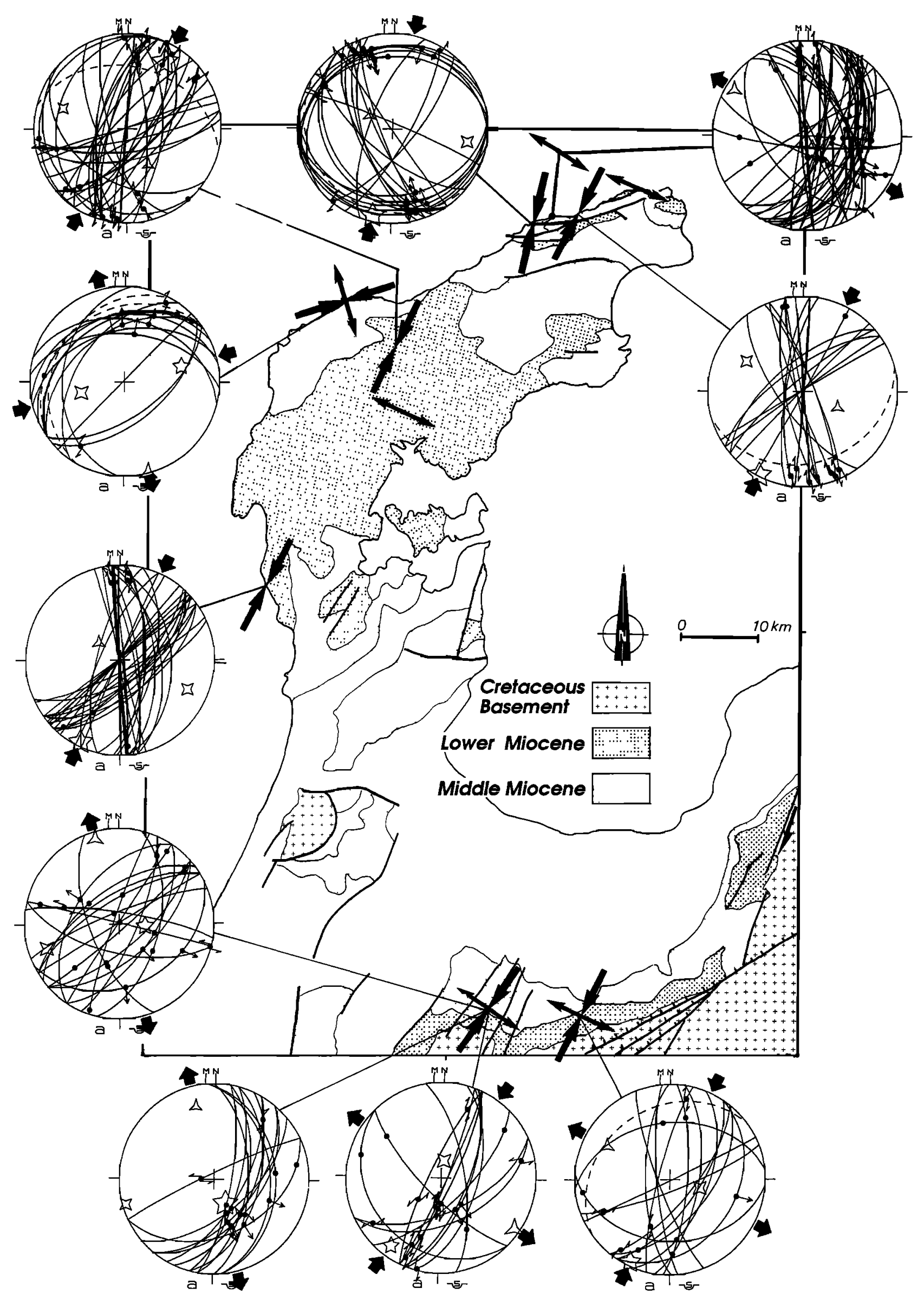

Fig. 18. Geological map of Noto Peninsula and Yatsuo basin and fault set measurements in lower and middle Miocene deposits. Strike-slip and normal faults are often associated, paleostress ficld is transtensional with $\sigma_{H \max }$ trending NE. 


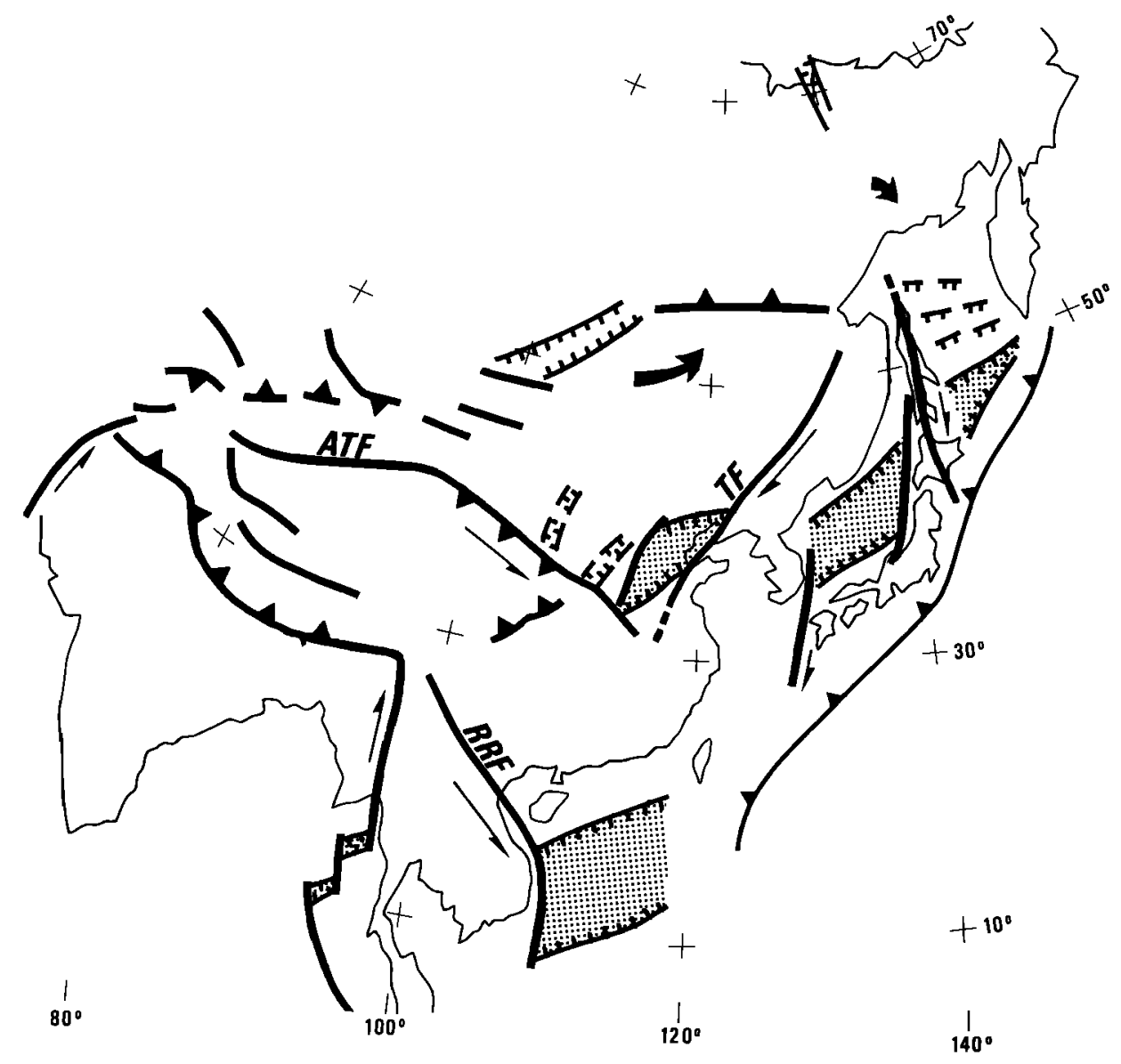

Fig. 19. Simplified model of deformation of Asia (oblique Mercator projection)[after Jolivet et al., 1990]. ATF is Altyn Tagh fault, RRF is Red River fault, and TF is Tanlu fault.

$\sigma_{H \max }$ in Sakhalin), and $\sigma_{H \max }$ became $\sigma_{1}$ all along the strike-slip zone. In the Japan arc the recent deformation is purely compressional with folds and reverse faults, while dextral motion is still active in Sakhalin. We therefore observe a different behavior between the northern intracontinental part of the strike-slip zone, transpressional since the Late Oligocene, and the southern part neighboring the subduction zone. The Japan Sea opened in a transtensional regime when the subduction boundary was stress-free. It began to close when subduction imposed a compressional regime perpendicular to the trenches [Nakamura and Uyeda, 1980] probably linked with the inception of subduction of the young oceanic lithosphere of the Philippine sea plate under the Japan arc during the late Miocene [e.g., Jolivet et al., 1989]. The geometry of the strike-slip zone is controlled by the variations of stress regime in the back arc region due to changing geodynamic conditions along the subduction zone. Thus the extensional component of the Japan Sea opening is likely to have been provided by back arc rifting probably due to trench retreat [Chase, 1978; Molnar and Alwater, 1978; Uyedo and Kanamori, 1979], and the strike-slip component is linked to some other mechanism such as the India-Asia collision as discussed by Kimura and Tamaki [1986] and Jolivet et al. [1990] (Figure 19). The model presented by Jolivet et al. [1990] is derived from Davy and Cobbold's [1988] experiments: it involves a wide left-lateral shear zone connecting the Pamir-Tien Shan ranges to the BaikalStanovoy regions which evolves from transpression to transtension. In the transtensional domain left-lateral shear is accommodated by rotation of large-scale dominos and dextral motion between them. An additional component can be added: the North America-Eurasia pole of rotation is located in east Siberia between the Laptev Sea and the Okhotsk Sea [Chapman and Solomon, 1976; Savostin et al., 1983; Cook et al., 1986] and has always been in this region since the early Eocene. This situation leads to extensional strain north of the rotation pole along the Nansen Ridge and Lena river mouth, and compressional strain south of it. The compression might be partly taken up by the southeastward extrusion of the Okhotsk block producing transpressional dextral shear in Sakhalin [Jolivet, 1986; Riegel et al., 1993].

To conclude, the Sakhalin-NE Japan strike-slip zone is a 2000-km-long crustal scale structure that penetrates inside Asia to the north and has guided the opening of the Japan Sea to the south along the Pacific subduction zone. Jolivet and Tamaki [1992] presented new reconstructions of the opening of the Japan Sea that allow a crude quantification of the finite dextral offset since $25 \mathrm{Ma}$ : at least $400 \mathrm{~km}$ of relative motion are necessary to accommodate the opening (Figure 20). It seems unlikely that this large offset has been accommodated only by the Tym-Poronaysk fault: most of the offset was probably taken up by offshore faults in the Tartary strait between Sakhalin and mainland Asia where the crust is the thinnest, and further south along the transition from continental (NE Japan arc) to oceanic crust (Japan basin).

In NE-Asia, dextral motion associated with extension is also evidenced by Chen and Nabelek [1988] along the Tanlu fault in the Bohai Gulf (Figure 19). It is not yet possible to 

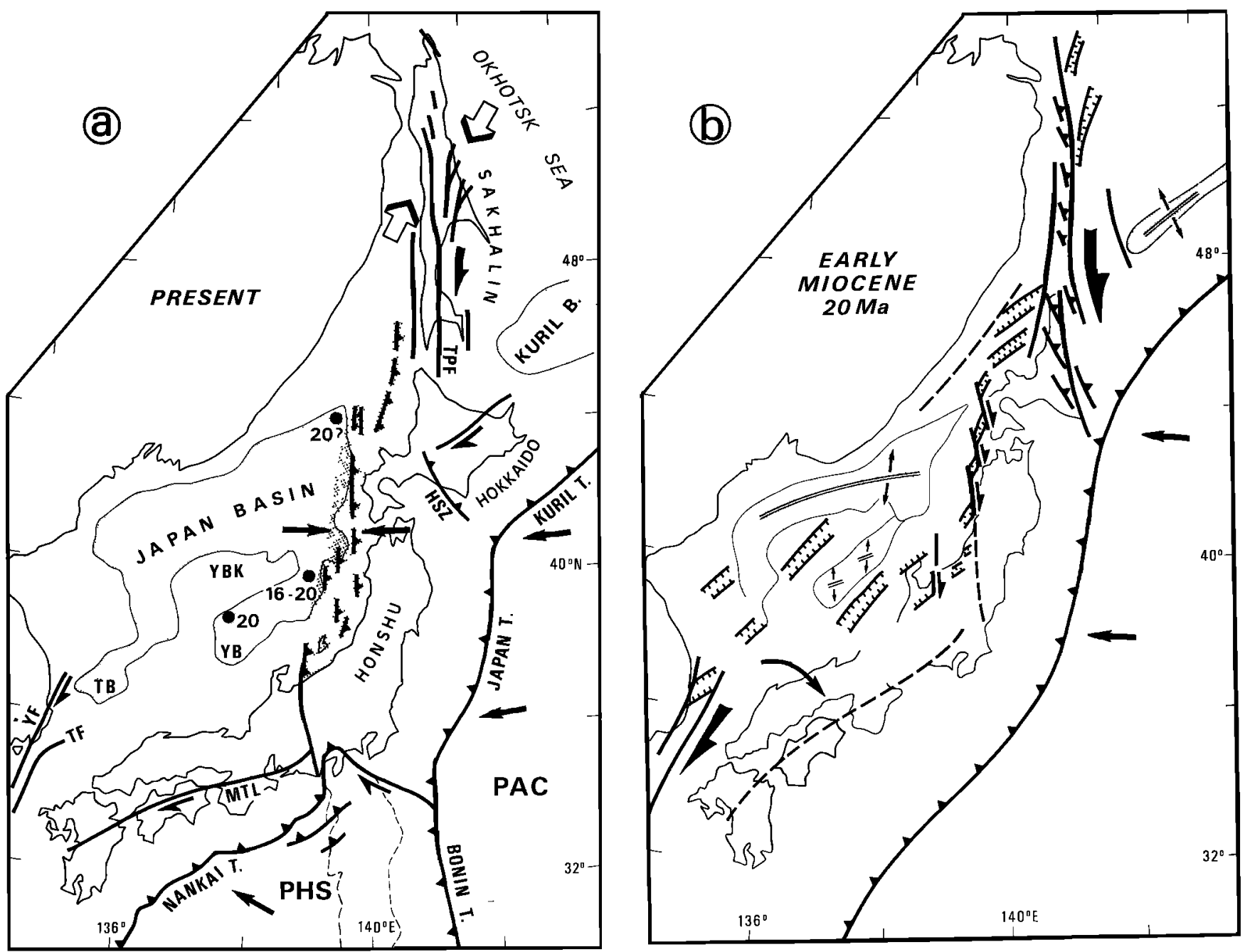

Fig. 20. (a) Present-day geodynamic context of Sakhalin and Japan Sea region. Shaded area represents the oceanic crust of Japan Sea and Kuril Basin. Darker shading shows the zone of active compression of eastem Japan Sea. (b) Same region 20 Ma ago, reconstruction parameters after Jolivet et al. [1991] and Jolivet and Tamaki [1992]. TPF is Tym-Poronaysk fault, HSZ is Hidaka Shear Zone, MTL is median tectonic line, YBK is Yamato Bank, YB is Yamato Basin, YF is Yangsan fault, TB is Tsushima Basin, and TF is Tsushima fault.

quantify the total amount of dextral offset taken up along the eastern border of Asia at the latitude of Japan during Neogene, but a minimum of 400 to $500 \mathrm{~km}$ is likely. This makes this cluster of dextral shear zones a first-order feature of Asia, as important as the Altyn Tagh fault or the Red River fault which accommodated also several hundreds of kilometers of leftlateral offset during Cenozoic (Figure 19) [Tapponnier and Molnar, 1977; Tapponnier et al., 1990]. If the strike-slip deformation is mostly localized along left-lateral faults immediately north and east of Tibet, close to the Indian indenter, it is mostly accommodated by dextral motion along antithetic N-S trending faults far from the indenter near the Pacific subduction. This emphasizes the role played by the Pacific subduction as an active extensional boundary, and implies that the geometry of deformation in Asia is controlled by two equally important lateral conditions: shortening along the Himalaya, and extension along the western Pacific subduction.

Acknowledgments. This work was funded by a CNRS-INSU grant (DBT 5-06) and supported by the Institute of Marine Geology and Geophysics, Yuzhno-Sakhalinsk. We are very grateful to K. Fujita for his constructive review. We thank Jacques Angelier for allowing us to use his brittle deformation analysis sofiware. We are also grateful to $O$.
A. Melnikov and V. S. Rozhdestvensky for their introduction to Sakhalin geology, and especially to Rima Kovalenko and Tania Godounova for their indispensable help in Sakhalin and Moscow. Special thanks are due to G. Marquis who kindly improved the english of the manuscript.

\section{REFERENCES}

Angelier, J., Tectonic analysis of fault slip data sets, J. Geophys. Res., $89,5835-5848,1984$.

Angelier, J., and P. Mechler, Sur une méthode graphique de recherche des contraintes principales également utilisable en tectonique et en sismologie, la méthode des dèdres droits, Bull. Soc. Géol. France, $19,1309-1318,1977$.

Antipov, M. P., V. M. Kovylin, and V. P. Filat'yev, Sedimentary cover of the deepwater basins of Tatar strait and the northern part of the sea of Japan, Int. Geol. Rev., 22(11), 1327-1334, 1979.

Briais A. P. Patriat and P. Tapponnier, Updated interpretation of magnetic anomalies and seafloor spreading stages in the South China Sea: implications for the tertiary tectonics of southeast Asia, $J$. Geophys. Res., 98, 6299-6328, 1993.

Cadet, J. P. et al. Deep scientific dives in the Japan and Kuril trenches, Earth Planet. Sci. Lett., 83, 313-328, 1987a.

Cadet, J. P., et al., The Japan trench and its juncture with the Kuril trench, cruise results of the Kaiko project, Leg 3, Earth Planet. Sci. Lett., 83, 267-284, $1987 \mathrm{~b}$.

Chamot-Rooke, N., and X. Le Pichon, Zenisu ridge: Mechanical model of formation, Teclonophysics, 160, 175-194, 1989.

Chapman, M.C., and S. C. Solomon, North American-Eurasian plate boundary in northeast Asia, J. Geophys. Res., 81, 921-930, 1976. 
Chase, C. G., Extension behind island arcs and motion relative to hotspots, J. Geophys. Res., 83, 5385-5387, 1978.

Chen, W. P, and J. Nabelek, Seismogenic strike-slip faulting and the development of the North China basin, Tectonics, 7, 975-989, 1988.

Cobbold, P.R. and P. Davy, Indentation tectonics in nature and experiments, 2, Central Asia, Bull. Geol. Instit. Univ. Uppsala, 14 143-162, 1988

Cook, D.B., K. Fujita, and C. A. Mac Mullen, Present day plate interactions in northeast Asia: North America, Eurasian and Okhotsk plates, J. Geodyn., 6, 33-51, 1986.

Curray, M. P., D. G. Moore, L. Lawver, F. J. Emmel, R. W. Raitt, M. Henry, and R. Kieckhefer, Tectonics of the Andaman Sea and Burma, Geological and Geophysical Investigations of Continental Margins, edited by J. S. Watkins, L. Montadert, and P. Dickerson, AAPG Mem., 29, 189-198, 1979.

Davy, P., and P. R. Cobbold, Indentation tectonics in nature and experiments. Experiments scaled for gravity, Bull. Geol. Instit. Univ. Upsalla, 14, 129-141, 1988.

Dziewonski, A. M., J. E. Franzen, and J. H. Woodhouse, Centroidmoment tensor solutions for October-December 1984, Phys. Earlh Planet. Inter., 39, 147-156, 1985.

Dziewonski, A. M., G. Ekstrom, J. E. Franzen, and J. H. Woodhouse, Global seismicity of 1979: centroid-moment tensor solutions for 524 earthquakes, Phys. Earth Planet. Inter., 48, 18-46, 1987.

England, P. and P. Molnar, Right-lareral shear and rotation as the explanation for strike-slip faulting in eastem Tibet, Nature, 344, 140$142,1990$.

Fukao, Y. and M. Furumoto, Mechanisms of large earthquakes along the eastem margin of the Japan Sea, Tectonophysics, 25, 247-266, 1975.

Geology of the USSR, vol. 33, Sakhalin Geological Description, 431 pp. Nedra, Moscow, 1970.

Gnibidenko, H.S., The Sea of Okhotsk-Kuril islands ridge and KurilKamchatka trench, in The Ocean Basins and Margins, vol. 7A, edited by A.E.N. Naim, F.G. Stehli and S. Uyeda, Pp. 377-418, Plenum, New York, 1985

Gnibidenko, H.S., and A. S. Svarichevsky, Tectonics of the south Okhotsk deep-sea basin, Tectonophysics, 102, 225-244, 1984

Holt, E. H., J. F. Ni, T. C. Wallace, and A. J. Haines, The active tectonics of the eastem Himalayan syntaxis and surrounding regions, J. Geophys. Res., 96, 14,595-14,632, 1991.

Huchon, P., Géodynamique de la zone de collision d'Izu et du point triple du Japon Central, thèse de doctorat, 414 pp., Univ. Pierre et Marie Curie, Paris, 1985.

Jolivet, L., America-Eurasia plate boundary in eastem Asia and the opening of marginal basins, Earth Planet. Sci. Lett., 81, 282-288, 1986.

Jolivet, L and P. Huchon, Crustal scale strike-slip deformation in Hokkaido, Northeast Japan, J. Struct. Geol., II, 509-522, 1989.

Jolivet, L., and S. Miyashita, The Hidaka Shear Zone (Hokkaido, Japan): Genesis during a right-lateral strike slip movement, Tectonics, 4, 289-302, 1985 .

Jolivet, L., and K. Tamaki, Neogene kinematics in the Japan Sea region and volcanic activity of the northeast -Japan arc, edited by Tamaki et al., Proc. Ocean Drill. Program, Sci. Results, 127/128, 1311-1331, 1992.

Jolivet, L., P. Huchon, and C. Rangin, Tectonic setting of Westem Pacific marginal basins, Tectonophysics, 160, 23-47, 1989.

Jolivet, L., P. Davy, and P. Cobbold, Right-lateral shear along the northwest Pacific margin and the India-Eurasia collision, Tectonics, 9, 1409-1419, 1990.

Jolivet, L., P. Huchon, J.P. Brun, N. Chamot-Rooke, X. Le Pichon, and J.C. Thomas, Arc deformation and marginal basin opening, Japan Sea as a case study, J. Geophys. Res., 96, 4367-4384, 1991.

Jolivet, L., M. Foumier, P. Huchon, V. S. Rozhdestvensky, K. F Sergeyev, and L. Oscorbin, Cenozoic intracontinental dextral motion in the Okhotsk-Japan Sea region, Tectonics, 11, 968-977, 1992.

Jun, M.S., Source parameters of shallow intraplate earthquakes in and around the Korean peninsula and their tectonic implication, Acta Univ. Ups. Abstr. Uppsala Diss. Fac. Sci., 285, 16, 1990.

Kaneoka, I., K. Notsu, Y. Takigami, K. Fujioka, and H. Sakai, Constrainis on the evolution of the Japan Sea based on 39Ar-40A ages and $\mathrm{Sr}$ isotopic ratios for volcanic rocks of the Yamato seamount chain in the Japan Sea, Earth Planet. Sci. Lett., 97, 211 $225,1990$.

Kimura, G., and K. Tamaki, Collision, rotation and back arc spreading: The case of the Okhotsk and Japan Seas, Tectonics, 5, 389-401, 1986.

Kimura, G., S. Miyashita, and S. Miyasaka, in Collision Tectonics in Hokkaido and Sakhalin, Accretion Tectonics in the Circum Pacific Regions, edited by M. Hashimoto and S. Uyeda, pp. 117-128, Terrapub, Tokyo, 1983.

Kimura, G. M. Sakakibara, H. Ofuka, H. Ishizuka, S. Miyashita, M. Okamura, O. A. Melinikov, and V. Lushchenko, A deep section of accretionary complex: Susunai complex in Sakhalin island, northwest Pacific margin, Isl. Arc, 1, 166-175, 1992.
Koshiya, S., Tanakura Shear Zone, the deformation process of fault rocks and its kinematics, J. Geol. Soc. Jpn., 92, 15-29, 1986.

Lallemand, S., and L. Jolivet, Japan Sea: A pull apart basin, Earth Planet. Sci. Lett. 76, 375-389, 1985.

Lallemant, S., N. Chamot-Rooke, X. Le Pichon, and C. Rangin, Zenisu Ridge: A deep intra-oceanic thrust related to subduction off Southwest Japan, Tectonophysics, 160, 151-174, 1989.

Le Pichon, el al., Nankai trough and the fossil Shikoku ridge: Results of Box 6 Kaiko survey, Earth Planet. Sci. Lett., 83, 186-198, 1987.

Le Pichon, X., K. Kobayashi, et al., Fluid venting activity within the eastem Nankai trough accretionary wedge: A summary of the 1989 Kaiko-Nankai results, Earth Planet. Sci. Lett., 109, 303-318, 1992

Matsuzaka, S., M. Tobita, and Y. Nakahori, Detection of Philippine sea plate motion by very long baseline interferometry, Geophys. Res. Lett., 18, 1417-1419, 1991.

Melnikov, O. A., Structure and Geodynamics of the Hokkaido-Sakhalin Folded Region (in Russian), 94 pp., Nauka, Moscow, 1987.

Melnikov, O. A., and V. S. Rozhdestvensky, Guide-Book for Geological Excursions on the Souhern Part of Sakhalin Island, edited by H. S. Gnibidenko, Yuzhno-Sakhalinsk, 1989.

Molnar, P., and T. Atwater, Interarc spreading and cordilleran tectonics as altemates related to the age of the subducted oceanic lithosphere, Earth Planet. Sci. Lett., 41, 330-340, 1978.

Molnar, P., and P. Tapponnier, Cenozoic tectonics of Asia: Effects of a continental collision, Science, $189,419-426,1975$

Nakamura, K., Possible nascent trench along the eastern Japan Sea as the convergent boundary between Eurasian and North American plates (in Japanese), Bull. Earthquake. Res. Inst. Univ. Tokyo, 58, $711-722,1983$

Nakamura, K., and S. Uyeda, Stress gradient in back arc regions and plate subduction, J. Geophys. Res., 85, 6419-6428, 1980

Nur, A., H. Ron, and O. Scotti, Fault mechanics and the kinematics of block rotations, Geology, 14, 746-749, 1986.

Oscorbin, L. S., Seismicity of the Sakhalin island, in Seismic Regions of the Kuril Islands, Primorja and Priamurjia, edited by S. L. Solovjev, pp. 143, Vladivostok, 1977.

Otsuki, K., Reconstruction of Neogene tectonic stress field of Northeast Honshu arc from metalli「erous veins, Mem. Soc. Geol. Jpn., 32, 281304,1989

Otsuki, K., Neogene tectonic stress fields of northeast Honshu Arc and implications for plate boundary conditions, Tectonophysics, 181, 151164,1990

Orsuki, K., and M. Ehiro, Major strike slip faults and their bearing on the spreading of the Japan Sea, J. Phys. Earth,26, suppl., 537-555, 1978.

Pushcharovskiy, Y. M. V. P. Zinkevich, A. O. Mazarovich, A. A Peyve, Y. N. Raznitsin, A. V. Rikhter, and N. V. Tsukanov, Overthrusts and imbricate structures of the northwestem Pacific margin, Geotectonics, 17, 466-477, 1983.

Ranken, B., R. K. Cardwell and D. E. Karig, Kinematics of the Philippine sea plate, Tectonics, 3, 555-575, 1984

Riegel, S.A., K. Fujita, B. M. Koz'min, V. S. Imaev, and D. B. Cook Extrusion tectonics of the Okhotsk plate, northeast Asia, Geophys. Res. Lett., 20, 607-610, 1993.

Rikhter, A. V., Structure and Tectonic Evolution of Sakhalin in the Mesozoic (in Russian), 90 pp., Nauka, Moscow, 1986.

Ron, H., R. Freund, Z. Garfunkel, and A. Nur, Block rotation by strike slip faulting, structural and paleomagnetic evidence, $J$. Geophys. Res., 89, 6256-6270, 1984.

Rozhdestvensky, V. S., The role of wrench-faults in the structure of Sakhalin, Geotectonics, 16, 323-332, 1982.

Rozhdestvensky, V. S., Evolution of the Sakhalin fold system, Tectonophysics, 127, 331-339, 1986.

Savostin, L., L. Zonenshain, and B. Baranov, Geology and plate tectonics of the Sea of Okhotsk, in Geodynamics of the Western Pacific-Indonesian Region, Geodyn. Ser., vol. 11, edited by T. W. C. Hilde and S. Uyeda, pp. 343-354, AGU, Washington, D.C., 1983.

Scotti, O., A. Nur, and R. Estevez, Distributed deformation and block rotation in three dimensions, J. Geophys. Res., 96, 12,225-12,243, 1991.

Seno, T., The instantaneous rotation vector of the Philippine sea plate relative to the Eurasian plate, Tectonophysics, 42, 209-226, 1977.

Sugi, N., K. Chinzei and S. Uyeda, Vertical crustal movements of northeast Japan since Middle Miocene, in Geodynamics of the Western Pacific-Indonesian Region, Geodyn. Ser., vol. 11, edited by T. W. C. Hilde and S. Uyeda, pp. 317-329, AGU, Washington, D.C., 1983.

Takeuchi, T., T. Ozawa, and K. Kodoma, Paleomagnetism of the late Cretaceous to Neogene deposits in central Hokkaido, Japan and south Sakhalin of the USSR: multiple rotations caused by transcurrent faults, paper presented at 29th International Geological Congress, Jpn. Geol. Soc., Kyoto, 24 August-3 September 1992.

Tamaki, K., Age estimation of the Japan Sea on the basis of stratigraphy, basement depth and heat flow data, J. Geomagn. Geoelectr., 38, 427-446, 1986.

Tamaki, K., Geological structure of the Japan Sea and its tectonic implications, Bull.Geol. Surv. Jpn., 39, 269-365, 1988. 
Tamaki, K. and E. Honza, Incipient subduction and obduction along the eastern margin of the Japan Sea, Tectonophysics, 119, 381-406, 1984.

Tamaki, K., K. Suyehiro, J. Allan, M. McWilliams, et al., Tectonic synthesis and implication of Japan Sea ODP drilling, Proc. Ocean Drill. Program, Sci. Resules, 1271128, 1333-1348, 1992.

Tapponnier, P., and P. Molnar, Slip line field theory and large-scale continental tectonics, Nature, 264, 319-324, 1976.

Tapponnier, P., and P. Molnar, Active faulting and tectonics in China, $J$. Geophys. Res., 82, 2905-2930, 1977.

Tapponnier, P., G. Peltzer, A. Y. Le Dain, and R. Amijo, Propagating extrusion tectonics in Asia: new insights from simple experiments with plasticine, Geology, 10, 611-616, 1982.

Tapponnier, P., G. Peltzer, and R. Armijo, On the mechanics of the collision between India and Asia, Collision tectonics, edited by M. P. Coward and A. C. Ries, Geol. Soc. Spec. Publ. London, 19, 115-157, 1986.

Tapponnier, P., R. Lacassin, P. H. Leloup, U. Shärer, Zhong Dalai, Wu Haiwei, Liu Xiohan, Ji Shaocheng, Zhang Lianshang, and Zhong Jiayou, The Ailao Shan/Red River metamorphic belt: Tertiary leftlateral shear between Indochina and South China, Nature, 343, 431 437, 1990.

Tarakamov, R. Z., and C. U. Kim, Seismofocal zones and geodynamics of the Kuril-Japan region, in Geodynamics of the Western PacificIndonesian Region, Geodyn. Ser., vol. 11, edited by T. W. C. Hilde and S. Uyeda, pp. 223-236, AGU, Washington, D.C., 1983.

Uyeda, S., and H. Kanamori, Back arc opening and the mode of subduction, J. Geophys. Res., 84, 1049-1061, 1979.

Von Huene, R., and S. Lallemand, Tectonic erosion of the Japan and Peru convergent margins, Geol. Soc. Am. Bull., I02, 704-720, 1990.
Yamagishi, H., and $Y$. Watanabe, Change of stress field of Late Cenozoic in Southwest Hokkaido, Japan, Investigation of geologic faults, dykes, ore veins and active faults, Monogr. Geol. Collabor. Jpn., 31, 321-332, 1986.

Yamaji, A., Rapid intra-arc rifting in Miocene Northeast Japan, Tectonics, 9, 365-378, 1990.

Zakharov, V. K., and G. G. Yakushko, Modem vertical crustal movement in southem Sakhalin as determined by repeated surveying Dokl. Akad. Nauk SSSR, Engl. Transl., 207, 40-45, 1972.

Zanyukov, V. N., The central Sakhalin fault and its role in the tectonic evolution of the island (in Russian), Dokl. Akad. Nauk SSSR, 196, 913-916, 1971.

Zomenshain, L.P., and L.A. Savostin, Geodynamics of the Baikal rift zone and plate tectonics of Asia, Tectonophysics, 76, 1-45, 1981.

Zonenshain, L. P., M. I. Kuzmin, and L. M. Natapov, Geology of the USSR: A plate-tectonic synthesis, in Geodyn. Ser., vol. 21, edited by B. M. Page, pp. 242, AGU, Washington, D. C., 1990.

M. Foumier, P. Huchon, and L. Jolivet, Laboratoire de Géologie, Département Terrre Atmosphère Ocean, Ecole Normale Supérieure, 24 rue Lhomond, 75231 Paris cedex 05, France.

L. S. Oscorbin and K. F. Sergeyev, Institute of Marine Geology and Geophysics, Far East Science Center, Yuzhno-Sakhalinsk, Russia.

(Received April 1, 1992;

revised July 6,1993 ;

accepted July 20,1993 . 